\title{
Mineral and textural transformations in mixtures of Al-rich and Al-K-rich clays with firing: Refractory potential of the fired products
}

\author{
Elisa Laita *, Blanca Bauluz, María José Mayayo, Alfonso Yuste \\ IUCA-Department of Earth Sciences, Faculty of Sciences, Universidad de Zaragoza, Pedro Cerbuna 12, 50009, Zaragoza, Spain
}

\section{A R T I C L E I N F O}

\section{Keywords:}

Bauxite

Illite- and kaolinite-rich clay

Mineral transformations

Mullite

Corundum

\begin{abstract}
A B S T R A C T
The present work analyses a set of cylinders manufactured by pressing and fired from $1000{ }^{\circ} \mathrm{C}$ to $1270{ }^{\circ} \mathrm{C}$, which are composed of pure Al-rich rocks (bauxite) and mixtures of bauxite with Al-K-rich clays. The aim of the study is to determine the mineral and textural transformations that take place in the mixtures with firing and their influence on the physical properties of the final products in order to evaluate their refractory potential by comparing them with various fired commercial bauxites. To this end, raw and fired samples were analysed by $\mathrm{X}$ ray diffraction, X-ray fluorescence, and optical and field emission scanning electron microscopy, and significant physical properties (e.g. density, linear shrinkage, porosity, colour, water absorption, thermal conductivity and point load resistance) were determined in the fired cylinders. The raw bauxite was mainly formed by boehmite, kaolinite and hematite whereas the illite- and kaolinite-rich clay was formed by quartz, illite and kaolinite. Kaolinite, illite and boehmite are not detected at $1000{ }^{\circ} \mathrm{C}$ and, from this temperature upwards, mullite, corundum, $\gamma-\mathrm{Al}_{2} \mathrm{O}_{3}$, hercynite, ilmenite, cristobalite and vitreous phase are formed. Changes in physical properties with rising temperature are associated with the mineralogical changes. The increases in density and linear shrinkage are related to the formation of vitreous phase and the crystallization of mullite, and correlate with the decrease in porosity, water absorption and thermal conductivity. The changes in the colour of the samples are related to the hematite content at each temperature, whereas the point load resistance is greater with higher corundum content. Both the firing temperature and the clay content play an important role in the refractory potential of the mixtures, since samples mixed with illite- and kaolinite-rich clay present similar properties at lower temperatures to those of the fired commercial bauxites.
\end{abstract}

\section{Introduction}

Bauxites (Al-rich rocks) and illite- and kaolinite-rich clays (Al- and Krich clays) are the most important raw materials in manufacturing refractory ceramics. For this reason, knowledge of the mineralogical and textural transformations that occur during the firing process, as well as their influence on the physical properties of the final products, is a matter of great interest in characterizing these materials and inferring their refractory potential [1-4].

The mineral transformations that take place when aluminium- and clay-rich materials are fired at high temperature are influenced by the mineralogical composition of the raw materials, their granulometry, the firing temperature and the atmosphere conditions of the oven $[5,6]$. To understand how the calcination process occurs, it is thus necessary to analyse the mineral reactions, textural variations and compositional changes of the initial phases with the increase in temperature at both micron- and nano-scale [2,4,7].

In the literature, there are numerous studies that report mineralogical and textural changes in illite- and kaolinite-rich clays $[4,8,9]$, pyrophyllite-rich clays or carbonate-rich clays [2,7] during firing processes.

Some of these studies have also reported modifications in physical properties with firing $[6,10,11]$. However, there are no investigations that have described in detail the mineral and textural transformations with firing in bauxite materials and their relationship with the physical properties. This is what the present study does.

Mullite and corundum are frequent phases in ceramic products, and their formation influences the porosity of ceramics $[4,12]$. The crystallization of new phases with firing is therefore of great interest. However, little attention has been paid to how mixtures of bauxite with Al-K-rich clays can affect the mineralogy and physical properties of the final products. The study of these mixtures fired at different temperatures

\footnotetext{
* Corresponding author. Department of Earth Sciences, Faculty of Sciences, Universidad de Zaragoza, Pedro Cerbuna 12, 50009, Zaragoza, Spain.

E-mail address: laita@unizar.es (E. Laita).
} 
allows their refractory potential to be characterized and is thus of great interest for engineering and industrial applications.

With the aim of analysing the refractory potential of the mixtures, this research shows that the mixture of illite- and kaolinite-rich clays with bauxite raw materials can affect the mineralogical transformations that occur with firing and thus their physical properties and refractory potential.

The research has two aims: 1) to determine in detail and using highresolution techniques the mineralogical and textural transformations that take place in the mixtures during the firing processes at different temperatures, and 2) to evaluate their influence on the physical properties (density, linear shrinkage, porosity, colour, water absorption, thermal conductivity and point load resistance) of the final products and, with these data, to deduce the refractory potential of the obtained products by comparing them with various fired commercial bauxites.

\section{Geological setting}

In the southern Pyrenean mountains (NE Spain), there are several karst bauxite deposits, which were opencast-mined during the 1990s. One of the most important bauxite sites in this area is the Sierra de Boada, where the bauxite used in this study was obtained (Fig. 1). Here, 15-20 m of bauxite levels are found overlying Middle Jurassic (Dogger) dolostones and covered by Upper Cretaceous (Cenomanian) sandstones. The Middle Jurassic dolostones are affected by a palaeokarstic surface, above which the bauxites are arranged. By contrast, the surface contact with the Upper Cretaceous sandstones at the top shows a flat geometry. The bauxites are of a clayey aspect, predominantly red and violet colours, and contain millimetric spherical ferruginous pisoids [13].

On the other hand, in the Iberian Range (NE Spain) there are illiteand kaolinite-rich clay deposits belonging to the Lower Cretaceous Escucha Formation (Fig. 1) [14]. This formation has been traditionally divided into three members: lower, middle and upper [15]. The lower member of the Escucha Formation is formed by abundant claystones with a high kaolinite content, which are currently mined by the ceramic and refractory industries $[4,16,17]$.

\section{Materials and methods}

\subsection{Samples and firing process}

The bauxite and the illite- and kaolinite-rich clay were milled under $100 \mu \mathrm{m}$. Pure bauxite (labelled as BX100) and mixtures of bauxite with the illite- and kaolinite-rich clay in $75 / 25$ and $50 / 50$ proportions (labelled as BX75 and BX50, respectively) were used to manufacture the cylinders ( $5 \mathrm{~cm}$ in diameter and $0.8 \mathrm{~cm}$ high) by pressing. The cylinders of the raw samples thus obtained were then fired in a Tecno-piro PR4T oven. The firing temperatures were $1000{ }^{\circ} \mathrm{C}, 1100{ }^{\circ} \mathrm{C}, 1200{ }^{\circ} \mathrm{C}$ and $1270{ }^{\circ} \mathrm{C}$ under oxidizing conditions, increasing the temperature in steps of $200{ }^{\circ} \mathrm{C} / \mathrm{h}$ and maintaining the maximum temperature for $2 \mathrm{~h}$. Cylinders made from the raw and the fired samples are shown in Fig. 2.

To deduce the refractory potential of the manufactured cylinders, three fired commercial bauxites were used to compare their mineralogical and physical properties with those of the cylinders.

\subsection{X-ray fluorescence and X-ray diffraction}

$\mathrm{X}$-ray fluorescence analysis was carried out for the three raw samples (BX50, BX75 and BX100) and for the illite- and kaolinite-rich clay at

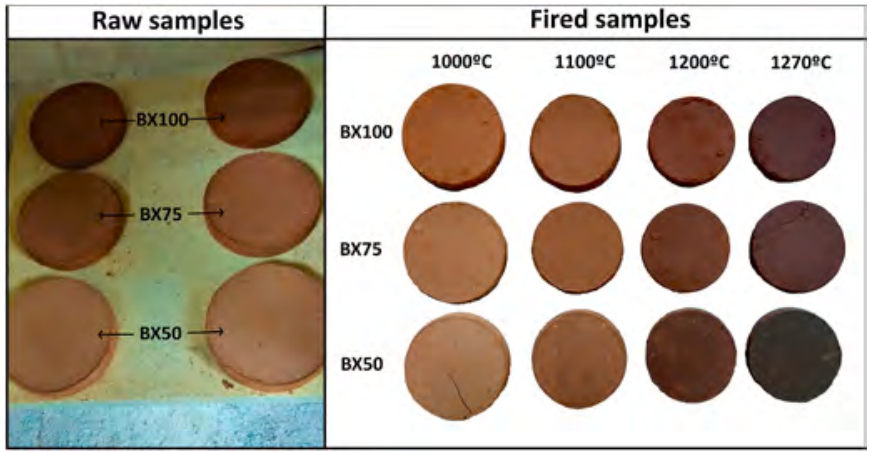

Fig. 2. Raw and fired cylinders obtained from pure bauxite (sample BX100) and mixtures of bauxite with the illite- and kaolinite-rich clay in 75/25 (sample BX75) and 50/50 proportions (sample BX50).

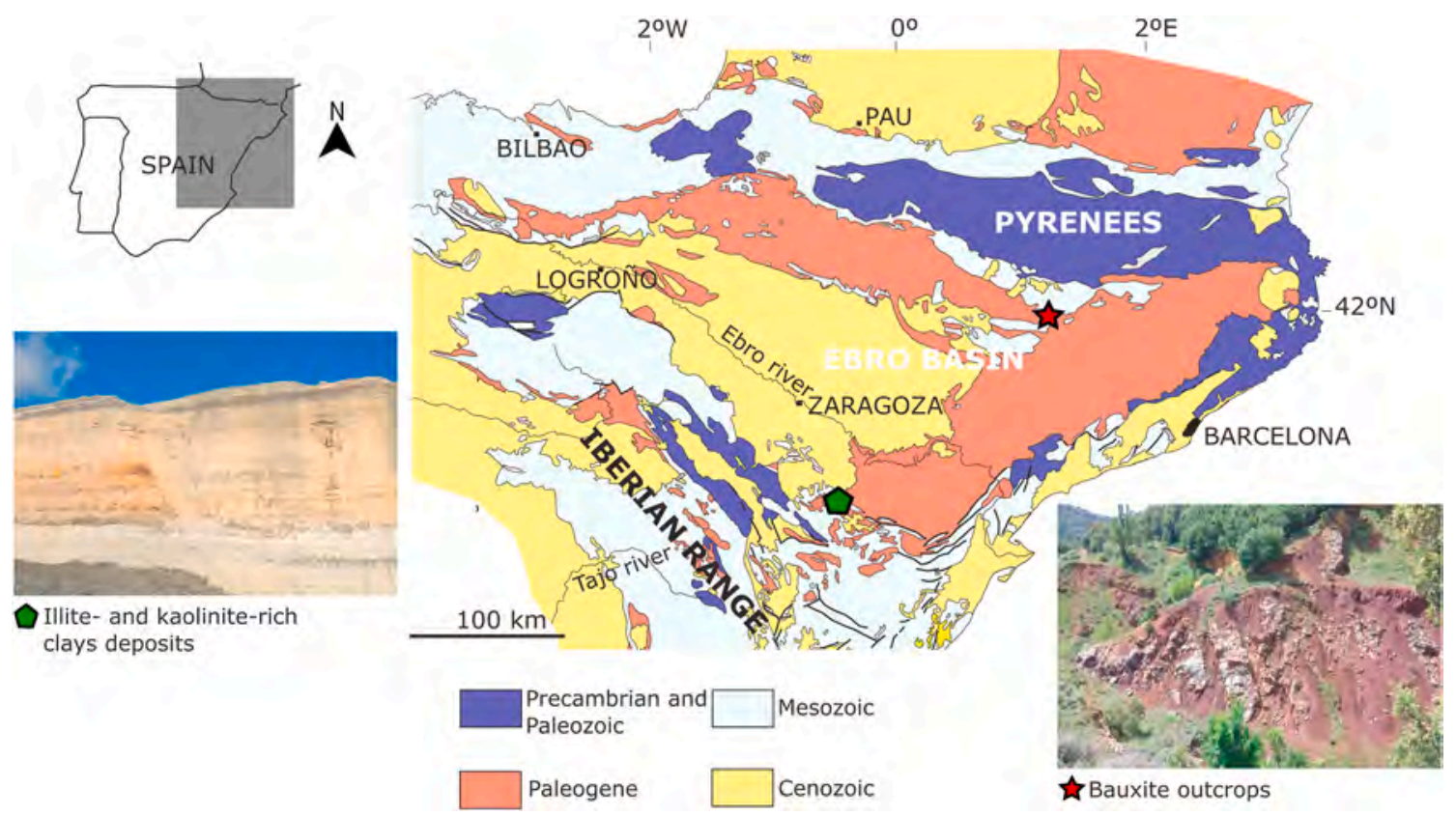

Fig. 1. Simplified geological map of the NE Iberian Peninsula indicating the location where the bauxite and the illite- and kaolinite-rich clays were obtained. 
Actlabs laboratories (Ontario, Canada) to obtain their chemical composition. Samples were fused in platine crucibles using an automated crucible fluxer, automatically poured into platine moulds for casting, and analysed on a Panalytical Axios Advanced wavelength dispersive XRF spectrometer. The detection limit of the technique was $0.01 \%$ for $\mathrm{SiO}_{2}, \mathrm{Al}_{2} \mathrm{O}_{3}, \mathrm{Fe}_{2} \mathrm{O}_{3}, \mathrm{MgO}, \mathrm{CaO}, \mathrm{Na}_{2} \mathrm{O}, \mathrm{K}_{2} \mathrm{O}, \mathrm{TiO}_{2}, \mathrm{P}_{2} \mathrm{O}_{5}$, and $\mathrm{Cr}_{2} \mathrm{O}_{3}, 0.005 \%$ for $\mathrm{Co}_{3} \mathrm{O}_{4}$ and $\mathrm{CuO}, 0.003 \%$ for $\mathrm{NiO}$ and $\mathrm{V}_{2} \mathrm{O}_{5}$, and $0.001 \%$ for $\mathrm{MnO}$.

Mineralogical analyses of both the raw and the fired samples as well as the three fired commercial bauxites were performed by X-ray diffraction (XRD). XRD patterns were obtained from the 3 to $60^{\circ} 2 \theta$ interval using a Philips 1710 diffractometer at the University of Zaragoza (Zaragoza, Spain) with $40 \mathrm{kV}$ voltage, $30 \mathrm{~mA}$ current, CuKa radiation, automatic slit and graphite monochromator. The goniometer velocity was $0.03^{\circ} 2 \theta / \mathrm{s}$ and the integration time was $1 \mathrm{~s}$. The recording was performed with XpowderX software [18].

After determining the mineral phases present in the samples, the relative proportions of these phases were ascertained using Reference Intensity Ratio (RIR) values from the literature [2,19-21]. To determine the formation of the vitreous phase in the samples during firing, the amorphous/crystals relationship was obtained using XpowderX software.

\subsection{Optical and electron microscopy studies}

Given that the XRD results showed similar mineralogical changes in samples fired at $1000{ }^{\circ} \mathrm{C}$ and $1100{ }^{\circ} \mathrm{C}$, thin sections of all the samples fired at $1000{ }^{\circ} \mathrm{C}, 1200{ }^{\circ} \mathrm{C}$ and $1270{ }^{\circ} \mathrm{C}$ were studied by transmitted and reflected light microscopy in order to identify the mineral phases and characterize their texture.

The same thin sections were analysed using a Carl Zeiss Merlin field emission scanning electron microscope (FESEM) with an Oxford energydispersive X-ray (EDS) detector at the University of Zaragoza (Zaragoza, Spain). The thin sections had been previously coated with carbon. Compositional images of the samples were obtained using two types of backscattered electron detectors: angular selective backscattered (AsB) and energy selective backscattered (EsB). The accelerating voltage was $15 \mathrm{kV}$ for AsB and $4 \mathrm{kV}$ for EsB, and the beam current was $400 \mathrm{pA}$ for AsB and $2.0 \mathrm{nA}$ for EsB. Semi-quantitative analyses were also performed by the energy-dispersive X-ray detector (EDS), which has a detection limit of $0.1 \%$. The accelerating voltage and the beam current for this detector were the same as those used for the AsB detector.

\subsection{Physical properties}

\subsubsection{Density and linear shrinkage (LS)}

The density was measured for both the raw samples and those fired at the different temperatures. The apparent density of the fired commercial bauxites was provided by the company.

The linear shrinkage of the fired samples was determined according to the following formula:

$\operatorname{LS}(\%)=\left(D_{1}-D_{2} / D_{1}\right) \times 100$

where $D_{1}$ is the diameter of the raw sample and $D_{2}$ is the diameter of the fired sample.

\subsubsection{Colour}

To determine the precise colour of the samples, an X.Rite portable spectrophotometer, model Ci6X, was used, which yields colour values in the Munsell system and in the CIE L*a*b* scale. The spectrophotometer was used to measure colour values in the raw and fired samples, as well as in the fired commercial bauxites.

\subsubsection{Porosity}

The porosimetric analysis was carried out in the Thermal Analysis and Porous Solids Unit of the University of Alicante (Spain). An Ultrapyc 1200e Helium Pycnometer was used to obtain the pore size and distribution in the fired samples, as well as their total porosity. The apparent porosity of the fired commercial bauxites was provided by the company.

\subsubsection{Water absorption (WA)}

Water absorption values were obtained for samples fired at the different temperatures according to the following formula:

$\mathrm{WA}(\%)=[(\mathrm{A}-\mathrm{B}) / \mathrm{B}] \times 100 \%$

where A is the weight of the wet cylinder after $3 \mathrm{~h}$ in a vacuum and B is the weight of the dry cylinder. The absorption capacity values of the fired commercial bauxites were provided by the company.

\subsubsection{Thermal conductivity ( $k$ )}

Samples mixed with the illite- and kaolinite-rich clay fired at $1200{ }^{\circ} \mathrm{C}$ seems to have similar physical properties to those of the fired commercial bauxites. For this reason, samples BX50, BX75 and BX100 fired at $1200{ }^{\circ} \mathrm{C}$ were selected to measure their thermal conductivity. Thermal conductivity values were obtained at room temperature by using a CTHERM Thermal Conductivity Analyzer, with an accuracy of $\pm 5 \%$. Ten measurements were made for each sample using Wakefield grease as the contact material. The setup of the equipment was previously checked using a standard sample (Pyroceram) suggested by the company.

\subsubsection{Point load test (PLT)}

The Point Load Test (PLT) allowed the Point Load Resistance Index $\mathrm{I}_{\mathrm{s}}$ (50) to be determined in samples fired at 1200 and $1270{ }^{\circ} \mathrm{C}$. Samples fired at 1000 and $1100{ }^{\circ} \mathrm{C}$ were not resistant enough to carry out the test. A point load measuring equipment was used to obtain the point load value of each sample $\left(I_{s}\right)$ in $\mathrm{kg} / \mathrm{cm}^{2}$. Several measures per sample (between 6 and 12 depending on sample availability) were carried out. To obtain the $I_{s(50)}$ index, a correction factor was necessary, according to the expression:

$\mathrm{I}_{\mathrm{s}(50)}=\mathrm{F} \cdot \mathrm{I}_{\mathrm{s}}$

$\mathrm{F}$ being the correction factor that was obtained using the following formula:

$\mathrm{F}=\left(\mathrm{D}_{\mathrm{e}} / 50\right)^{0.45}$

where $D_{e}$ is the equivalent diameter of the regular prisms, which can be calculated by means of the expression:

$\mathrm{D}_{\mathrm{e}}^{2}=4 \mathrm{~A} / \pi$

where $\mathrm{A}$ is the minimum cross-sectional area containing the two load application points.

\section{Results}

\section{1. $X R F$ and $X R D$ results}

The XRF results (Fig. 3) show that the illite- and kaolinite-rich clay presents higher proportions of $\mathrm{SiO}_{2}(57.76 \%)$ and $\mathrm{K}_{2} \mathrm{O}(3.47 \%)$ but lower proportions of $\mathrm{Al}_{2} \mathrm{O}_{3}$ (24.34\%) and $\mathrm{Fe}_{2} \mathrm{O}_{3}$ (3.36\%) than samples BX100, BX75 and BX50. Of these three samples, sample BX100 presents the highest $\mathrm{Al}_{2} \mathrm{O}_{3}$ and $\mathrm{Fe}_{2} \mathrm{O}_{3}$ contents and the lowest $\mathrm{SiO}_{2}$ and $\mathrm{K}_{2} \mathrm{O}$ contents.

The loss of ignition (LOI) produced in all the samples is related to the loss of the $\mathrm{OH}$ groups of the phyllosilicates and the hydroxides. As will be seen below, raw sample BX100 has the highest total boehmite + clay minerals content, which may be the cause of its higher LOI percentage (11.62\%).

The XRD patterns and the relative proportions of the different phases obtained from the raw and the fired samples are represented in Fig. 4. 


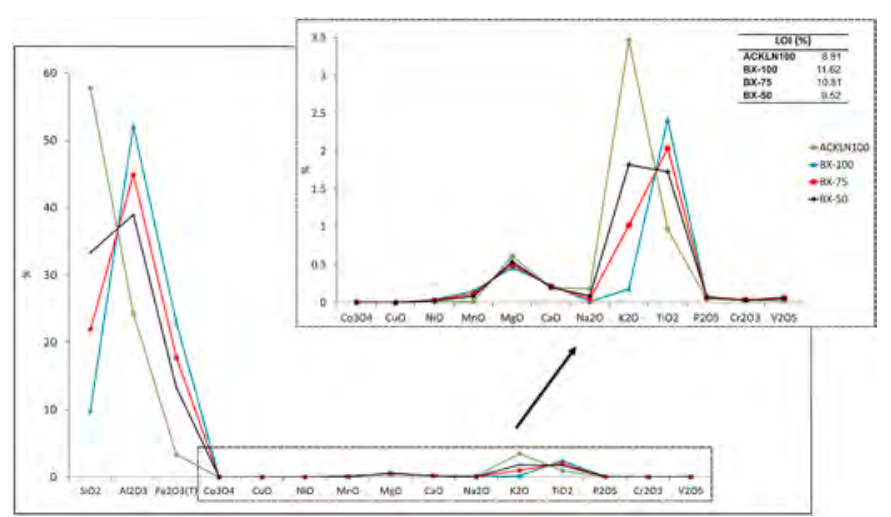

Fig. 3. XRF results showing the contents of major and several minor elements in the illite- and kaolinite-rich clay (ACKLN100) and the raw cylinders (BX100, BX75 and BX50).

The pure bauxite (sample BX100) is mainly formed by boehmite (62\%), kaolinite (25\%), hematite (9\%) and minor proportions of anatase, goethite and rutile $(<5 \%)$. Sample BX75 is formed by boehmite (43\%), illite-kaolinite (35\%), quartz (12\%) hematite $(6 \%)$ and minor proportions of anatase and rutile $(<5 \%)$. Sample BX50 is composed of illite-kaolinite (46\%), boehmite (27\%), quartz $(20 \%)$ and minor proportions of hematite, anatase and rutile $(<5 \%)$. By contrast, the illiteand kaolinite-rich clay is mainly formed by illite (39\%), quartz (32\%) and kaolinite (23\%), with minor proportions of orthoclase and albite $(<5 \%)$.

The kaolinite, illite, boehmite, anatase and goethite present in the raw samples are not detected from $1000{ }^{\circ} \mathrm{C}$ upwards, indicating that they are the least stable phases during the firing process. By contrast, quartz, hematite and rutile are still detected at $1270{ }^{\circ} \mathrm{C}$, showing that these are more stable phases, which withstand higher temperatures. However, the quartz content in samples BX75 and BX50 decreases with temperature, indicating that it is partially destabilizing. The hematite content increases in all the samples at $1000{ }^{\circ} \mathrm{C}(15-29 \%)$ compared to the raw samples $(<5 \%-9 \%)$ but then decreases with increasing temperature, also indicating that it is partially destabilizing.

At $1000^{\circ} \mathrm{C}$, ilmenite, cristobalite, $\gamma$-alumina, corundum ( $\alpha$-alumina), hercynite ( $\mathrm{Fe}$ and $\mathrm{Al}$ spinel) and mullite are formed. It was not possible to obtain a RIR value for the $\gamma$-alumina, so it was not semi-quantified. At this temperature, the XRD results also show the presence of amorphous phase, indicating the occurrence of fusion processes.

Ilmenite $(<5-10 \%)$ and cristobalite $(<5 \%)$, which formed at $1000^{\circ} \mathrm{C}$ in all the samples, are later destabilized, as their content decreases with temperature.

Corundum is detected from $1000{ }^{\circ} \mathrm{C}$ upwards; its content is higher at $1100{ }^{\circ} \mathrm{C}$ in all the samples and then it decreases with temperature, especially in samples BX75 and BX50. At $1270{ }^{\circ} \mathrm{C}$ the corundum content is higher in the BX100 sample (43\%) than in BX75 and BX50 (12 and 7\%, respectively).

Finally, the mullite content increases with temperature in all the samples. By contrast with corundum, its content is higher in samples BX75 and BX50 (79 and 77\% respectively) than in sample BX100 (44\%) at the highest temperature.

The relative proportions obtained from the fired commercial bauxites indicate that they are mainly composed of corundum (70-84\%) and mullite (14-27\%), and some of them occasionally present low contents of hematite, rutile, ilmenite and hercynite $(<5 \%)$.

The amorphous/crystals relationship obtained by XpowderX software is represented in Table 1. According to these data, an amorphous phase is generated in the three samples from $1000{ }^{\circ} \mathrm{C}$ upwards, its content seeming to rise with temperature up to $1200^{\circ} \mathrm{C}$ in samples BX75 and BX50. In addition, the amorphous phase content in the three samples is higher than that detected in the fired commercial bauxites.

\subsection{Optical and electron microscopy results}

\subsubsection{Optical and backscattered electron (BSE) images}

At optical microscopy resolution, at $1000{ }^{\circ} \mathrm{C}$ samples BX50 and BX75 show a fine-grained matrix, in which morphologies of the original phyllosilicates are still distinguished along with oxides and quartz fragments (10-80 $\mu \mathrm{m})$ (Fig. 5a), whereas in sample BX100 only small hematite aggregates $(<50 \mu \mathrm{m})$ are observed. With the increase in temperature, the texture of the three samples becomes very homogeneous. Scarce quartz fragments are still distinguished, which are smaller $(10-50 \mu \mathrm{m})$ than at lower temperatures, along with hematite aggregates and replacement textures involving hematite and another unidentified opaque mineral (Fig. 5b).

BSE images show remarkable textural and mineralogical changes with the increase in firing temperature. At $1000{ }^{\circ} \mathrm{C}$ rock fragments are still identified in samples BX100, BX75 and BX50. Iron and titanium oxides are recognized in some of these rock fragments, where they mainly occur in disseminated form, whereas other rock fragments are more homogeneous and contain almost no oxides. The rock fragments with abundant oxides seem to come from the original bauxite, whereas the most homogeneous ones seem to come from the illite- and kaoliniterich clay (Fig. 5c). Some of the oxides have compositional zonation, with rutile and ilmenite or ilmenite and hematite compositions (Fig. 5d and e), and iron and titanium oxides forming aggregates (10-30 $\mu \mathrm{m})$ are also recognized (Fig. 5e). At this temperature, in samples BX75 and BX50, quartz fragments $(1-20 \mu \mathrm{m})$ are observed that are not yet destabilized, and corundum crystals are present in the three samples, with acicular morphologies, nanometric lengths $(50-400 \mathrm{~nm})$ and random orientation (Fig. 5f). Kaolinite-type morphologies are differentiated in the three samples (Fig. 5d and f) and in almost all cases their sheets are separated. These morphologies could correspond at least in part to metakaolinites, since kaolinite was not detected by XRD at this temperature.

At $1200{ }^{\circ} \mathrm{C}$ the texture of the samples is much more homogeneous, possibly due to the vitrification process. Some of the rock fragments are still recognized, especially in sample BX100, indicating that bauxite may be the component most resistant to firing. In this sample, all the iron and titanium oxides are disseminated or form aggregates. By contrast, in samples BX75 and BX50 the rock fragments are not so easily distinguishable, and oxides are concentrated in certain areas, as well as forming aggregates. Instead of rock fragments, texturally and compositionally different areas can be discerned: homogeneous areas without oxides and more heterogeneous areas with iron and titanium oxides, both disseminated and aggregated (Fig. 6a). These different areas could correspond with the previous bauxite and illite- and kaolinite-rich clay fragments observed at $1000^{\circ} \mathrm{C}$. Sample BX100 (Fig. 6b) does not contain rock fragments of the illite- and kaolinite-rich clay, but the XRD results showed that the raw sample contained kaolinite. Thus, the homogeneous areas in BX100 may come from the destabilization of the initial kaolinite during firing. In general, the homogeneous areas are formed by acicular and prismatic nanometre-sized mullite crystals (100-600 nm), with random orientation and immersed in vitreous phase (Fig. 6a, b and c) along with quartz fragments, which present reaction edges, indicating that they have begun to destabilize (Fig. 6c). The heterogeneous areas in all the samples, where the oxides are concentrated, also contain abundant acicular corundum crystals, with random orientation and sizes larger than those found at $1000{ }^{\circ} \mathrm{C}(200 \mathrm{~nm}-2 \mu \mathrm{m})$. These corundum crystals can be found replacing hematite (Fig. $6 \mathrm{a}$, b and d).

Finally, at $1270{ }^{\circ} \mathrm{C}$ the texture of the three samples is very homogeneous (Fig. 7a). Iron and titanium oxides are less frequent and occur in the same form as at $1200{ }^{\circ} \mathrm{C}$. Quartz fragments only remain in sample BX50 although they are scarcer than at lower temperatures and show reaction edges. Mullite crystals are also found immersed in vitreous phase but with larger sizes $(100 \mathrm{~nm}-2 \mu \mathrm{m})$ (Fig. $7 \mathrm{~b}$ and $\mathrm{d})$. The corundum has acicular and prismatic morphologies with larger sizes $(200 \mathrm{~nm}-4 \mu \mathrm{m})$ and is immersed in a probably vitreous phase, occasionally replacing hematite (Fig. $7 \mathrm{c}$ and d). 


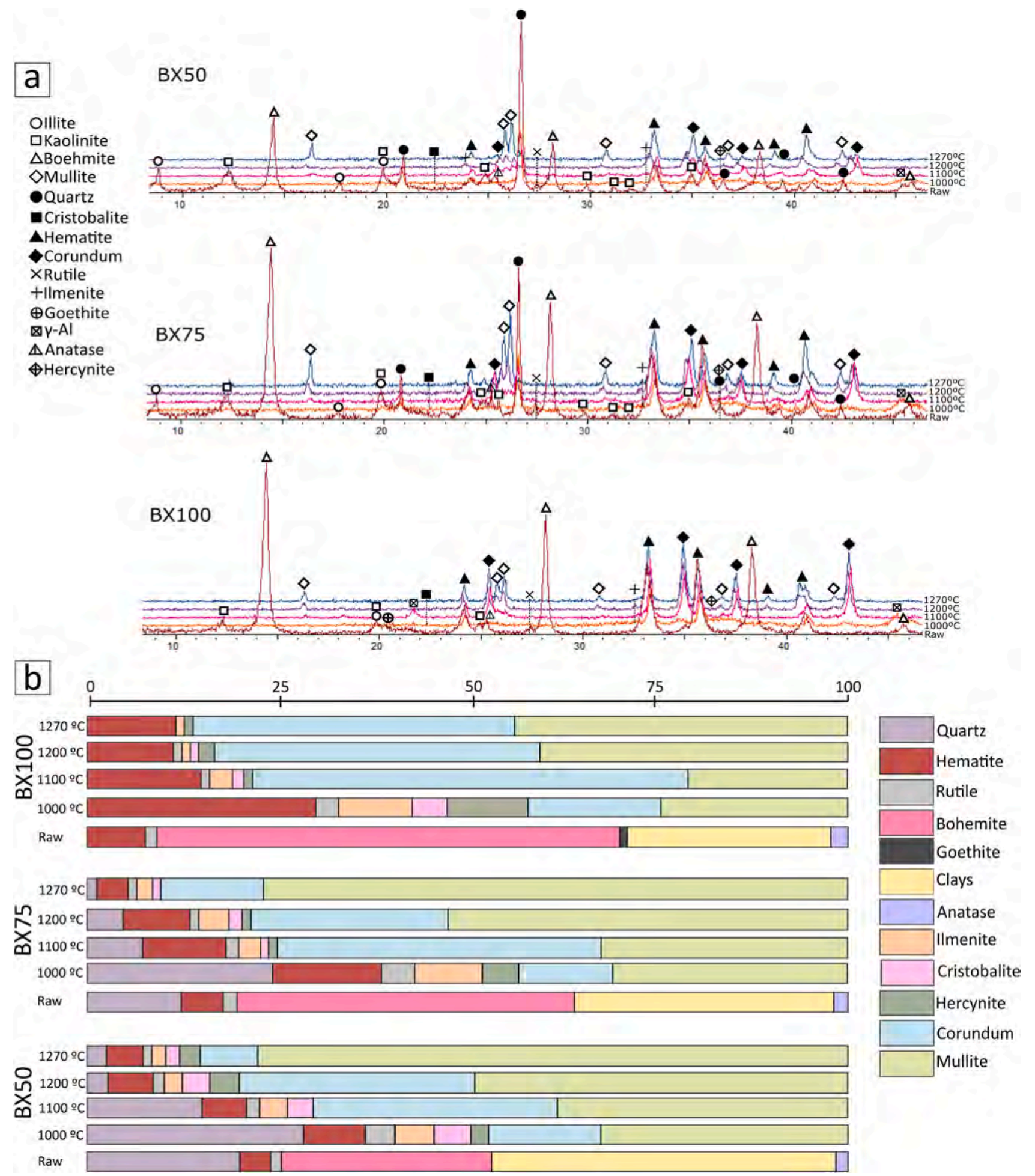

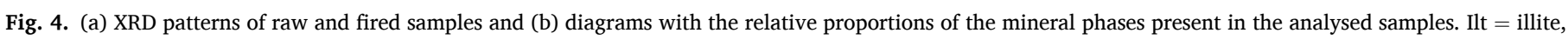

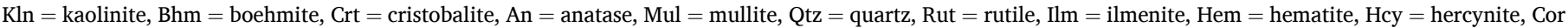
= corundum.

\subsubsection{Chemical analysis}

EDS analyses indicate that hematite, corundum and ilmenite show compositional differences from sample to sample and even at sample scale. $\mathrm{Al}$ vs. Fe (wt\%) plots at the different temperatures for the three samples show a trend among hematite, hercynite and corundum compositions (Fig. 8a, b and c). The Al vs. Fe plots show the presence of three compositional populations: 1) Fe-rich compositions that indicate hematite, 2) Al-rich compositions that are regarded as corundum, and 3) intermediate compositions between hematite and corundum.

Although hercynite was not clearly differentiated by FESEM analyses, it was detected by XRD in all the samples at the different temperatures, and some of the intermediate compositions included between hematite and corundum are close to theoretical hercynite $(31.05 \% \mathrm{Al}$, $32.13 \% \mathrm{Fe}, 36.82 \% \mathrm{O}$ ). 
Table 1

Amorphous/crystals relationship obtained by XpowderX software for the three samples at the different temperatures and for the commercial bauxites.

\begin{tabular}{lll}
\hline Sample & $\mathrm{T}^{\circ}$ & Amorphous/Crystals relationship \\
\hline BX100 & 1000 & 0.146 \\
& 1100 & 0.088 \\
& 1200 & 0.091 \\
BX75 & 1270 & 0.106 \\
& 1000 & 0.139 \\
& 1100 & 0.153 \\
BX50 & 1200 & 0.148 \\
& 1270 & 0.097 \\
& 1000 & 0.089 \\
& 1100 & 0.110 \\
Commercial bauxites & 1200 & 0.225 \\
& & 0.120 \\
& & 0.038 \\
& & 0.044 \\
\hline
\end{tabular}

Ti vs. Fe (wt\%) plots at the different temperatures for the three samples also show a trend among hematite, ilmenite and rutile compositions (Fig. 8d, e and f). In this case, compositions with Fe contents higher than $79 \%$ and $\mathrm{Ti}$ contents lower than $9 \%$ were considered hematite. Those compositions with Ti contents of $32-66 \%$ and Fe contents of $33-67 \%$ were considered ilmenite, whereas compositions with $\mathrm{Ti}$ contents higher than $75 \%$ and $\mathrm{Fe}$ contents lower than $25 \%$ were considered rutile.

Of all these phases, corundum and ilmenite are the two generated due to the firing process, as they were not detected by XRD in the raw samples. On average, the corundum composition at the different temperatures is close to theoretical corundum $(52.093 \% \mathrm{Al}$ and $47.07 \%$ O); it has an $\mathrm{Al}$ content of $44.07 \%$, but it also contains $\mathrm{Fe}(6.72 \%), \mathrm{Si}$ $(3.82 \%)$ and minor proportions of $\mathrm{Ti}(0.43 \%)$ and $\mathrm{K}(0.15 \%)$. Ilmenite presents lower $\mathrm{Ti}$ and Fe contents (20.35 and $28.35 \%$ respectively) than theoretical ilmenite $(31.56 \% \mathrm{Ti}, 36.81 \% \mathrm{Fe}$ and $31.63 \% \mathrm{O})$.

The Al vs. Si plot (Fig. 8g) shows mullite analyses from all the samples at the different temperatures. According to these results, the mullite presents a heterogeneous compositional range with compositions between kaolinite (or metakaolinite) and mullite. Those analyses at $1000{ }^{\circ} \mathrm{C}$ close to the theoretical kaolinite composition correspond with the kaolinite-type morphologies observed in the backscattered electron images. Although mullite presents a heterogeneous compositional range, its $\mathrm{Al} / \mathrm{Si}$ ratio increases from 1.49 at $1200{ }^{\circ} \mathrm{C}$ to 1.76 at $1270{ }^{\circ} \mathrm{C}$.

Finally, the vitreous mass observed in all the studied samples in which mullite and corundum crystals are immersed probably corresponds with the amorphous phase deduced from XRD. It presents a heterogeneous composition mainly formed by $\mathrm{Si}$ and $\mathrm{Al}$ (28.20 and $15.90 \%$, respectively), along with $\mathrm{Fe}$ and $\mathrm{K}$ (3.56 and $3.20 \%$, respectively) and minor proportions of $\mathrm{Ti}(0.64 \%), \mathrm{Mg}(0.44 \%), \mathrm{Ca}(0.16 \%)$ and $\mathrm{Na}(0.13 \%)$.
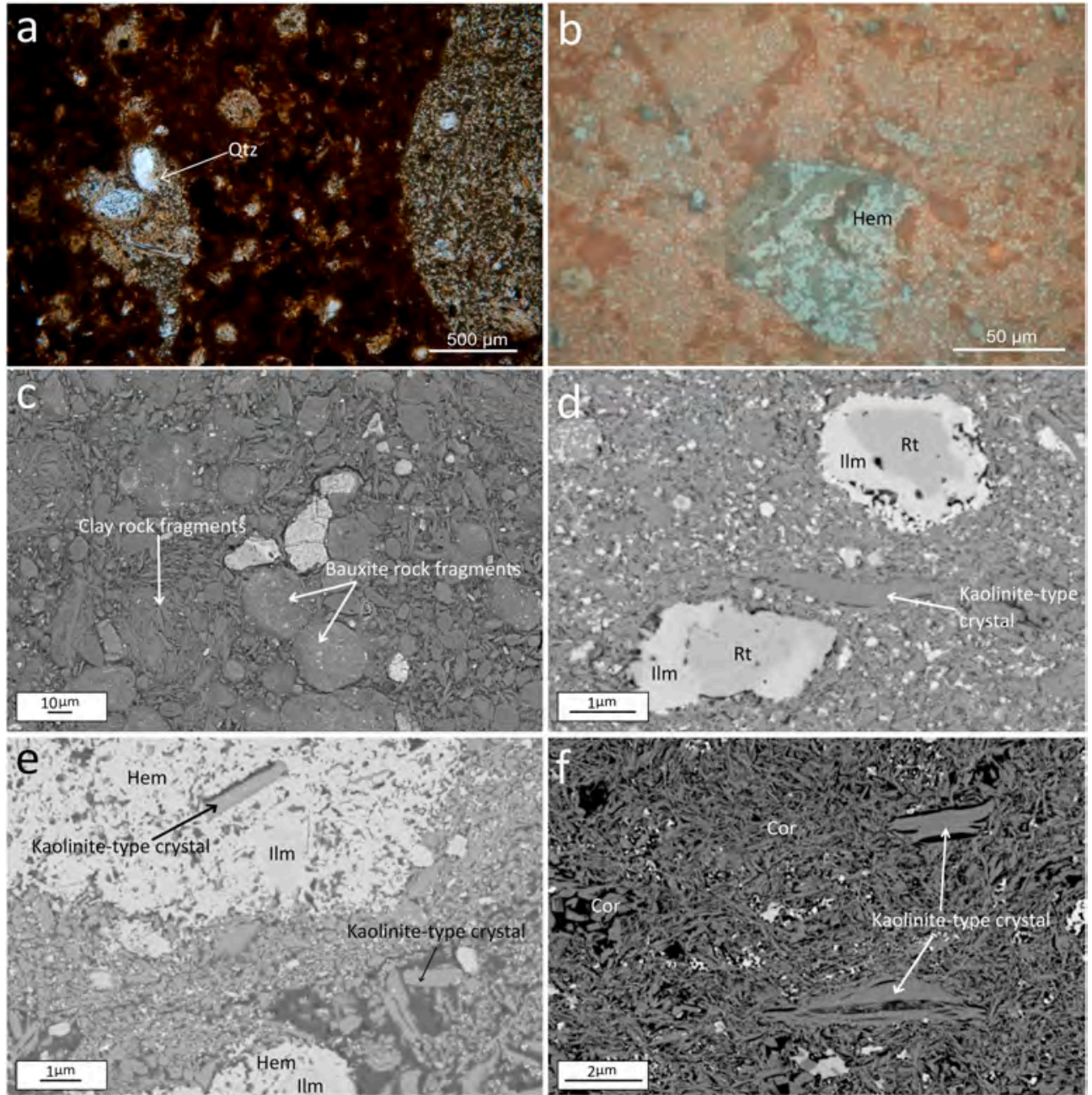

Fig. 5. (a) Transmitted light optical microscope images showing the matrix formed by quartz fragments and oxides in sample BX50 at $1000{ }^{\circ} \mathrm{C}$. (b) Reflected light optical microscope images showing hematite replacement textures in sample BX100 at $1270{ }^{\circ} \mathrm{C}$. (c-f) FESEM images of samples fired at $1000{ }^{\circ} \mathrm{C}$ showing: (c) Bauxite and clay rock fragments along with iron oxide aggregates in sample BX50. (d) Crystals with compositional zonation involving rutile and ilmenite compositions, and kaolinite-type crystals in sample BX100. (e) Oxide aggregate composed mainly of hematite and kaolinitetype crystals in sample BX75. (f) Acicular corundum crystals and kaolinite-type crystals with separated sheets in sample BX100. $\mathrm{Qtz}=$ quartz, $\mathrm{Rt}=$ rutile, $\mathrm{Ilm}=$ ilmenite Hem $=$ hematite, Cor $=$ corundum . 

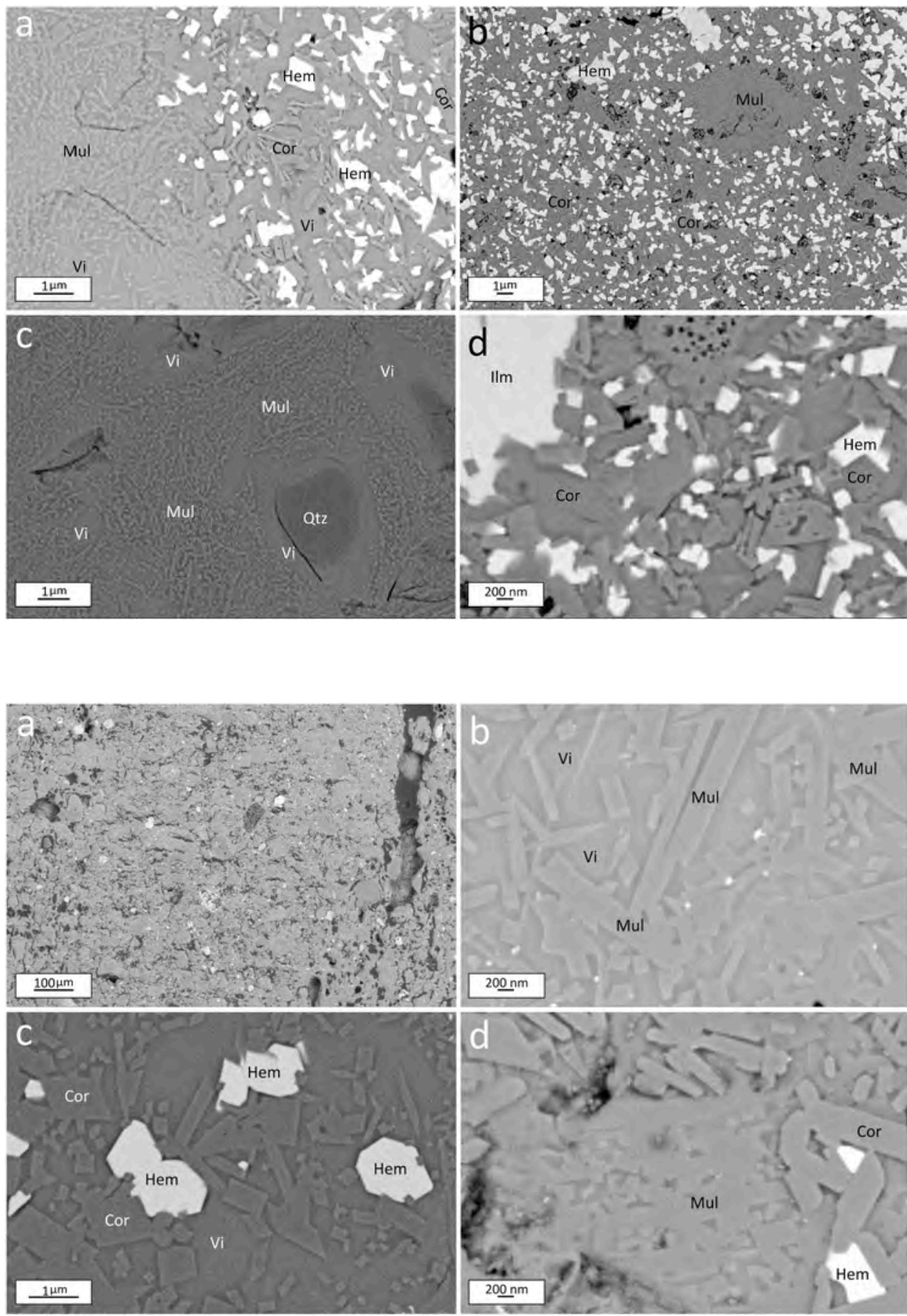

Fig. 6. FESEM images of samples fired at $1200{ }^{\circ} \mathrm{C}$ showing: (a) A homogeneous area with acicular mullite crystals and vitreous phase and a heterogeneous area with hematite and corundum crystals in sample BX75. (b) The same zones in sample BX100, in which the corundum content is higher and the mullite content is lower than in the other samples. (c) Quartz fragments with reaction edges, acicular mullite crystals and vitreous phase in sample BX50. (d) Corundum replacing hematite in sample $\mathrm{BX50.}$ Mul = mullite, Hem = hematite, $\mathrm{Cor}=$ corundum, $\mathrm{Vi}=$ vitreous phase, Qtz = quartz, Ilm = ilmenite.

\subsection{Physical properties}

\subsubsection{Density and linear shrinkage}

The density of the cylinders is $1.73 \mathrm{~g} / \mathrm{cm}^{3}, 1.74 \mathrm{~g} / \mathrm{cm}^{3}$ and $1.71 \mathrm{~g} /$ $\mathrm{cm}^{3}$ for samples BX100, BX75 and BX50, respectively. The changes in the density values of the three samples are represented in Fig. 9a, which shows that the density values of the raw samples remain almost constant up to $1000{ }^{\circ} \mathrm{C}$. At $1100{ }^{\circ} \mathrm{C}$ and $1200{ }^{\circ} \mathrm{C}$ the density increases in all the samples, reaching values of $2.83 \mathrm{~g} / \mathrm{cm}^{3}, 2.73 \mathrm{~g} / \mathrm{cm}^{3}$ and $2.55 \mathrm{~g} / \mathrm{cm}^{3}$ for samples BX100, BX75 and BX50, respectively. Finally, at $1270{ }^{\circ} \mathrm{C}$ the density of samples BX75 and BX50 decreases to $2.55 \mathrm{~g} / \mathrm{cm}^{3}$ and $2.43 \mathrm{~g} /$ $\mathrm{cm}^{3}$, respectively, whereas the density of sample BX100 increases to $3.43 \mathrm{~g} / \mathrm{cm}^{3}$. The density values reached by sample BX75 fired at $1200{ }^{\circ} \mathrm{C}$ and by sample $\mathrm{BX} 100$ fired at $1200^{\circ} \mathrm{C}$ and $1270{ }^{\circ} \mathrm{C}$ are the closest to the density values given for the fired commercial bauxites $\left(2.8-3.25 \mathrm{~g} / \mathrm{cm}^{3}\right)$. A similar trend is observed in the linear shrinkage values (Fig. 9b). At $1000{ }^{\circ} \mathrm{C}$ the linear shrinkage value is $4.39 \%$ for sample $\mathrm{BX} 100,3.99 \%$ for sample BX75, and $2.97 \%$ for sample BX50. A notable increase in the linear shrinkage is observed in the three samples at $1100{ }^{\circ} \mathrm{C}$ and $1200{ }^{\circ} \mathrm{C}$ with values of $12.43 \%$ and $18.55 \%$ for sample $\mathrm{BX} 100,11.86 \%$ and $16.74 \%$ for sample BX75, and $9.97 \%$ and $14.95 \%$ for sample BX50. Finally, at $1270{ }^{\circ} \mathrm{C}$ the linear shrinkage values undergo a slight decrease in samples BX75 and BX50 (15.07\% and 14.32\%, respectively), whereas the value increases in sample BX100 (22.56\%).

\subsubsection{Colour}

According to the Munsell System (Fig. 10a), the BX100 and BX75 raw samples present a reddish brown colour, which changes to bright 

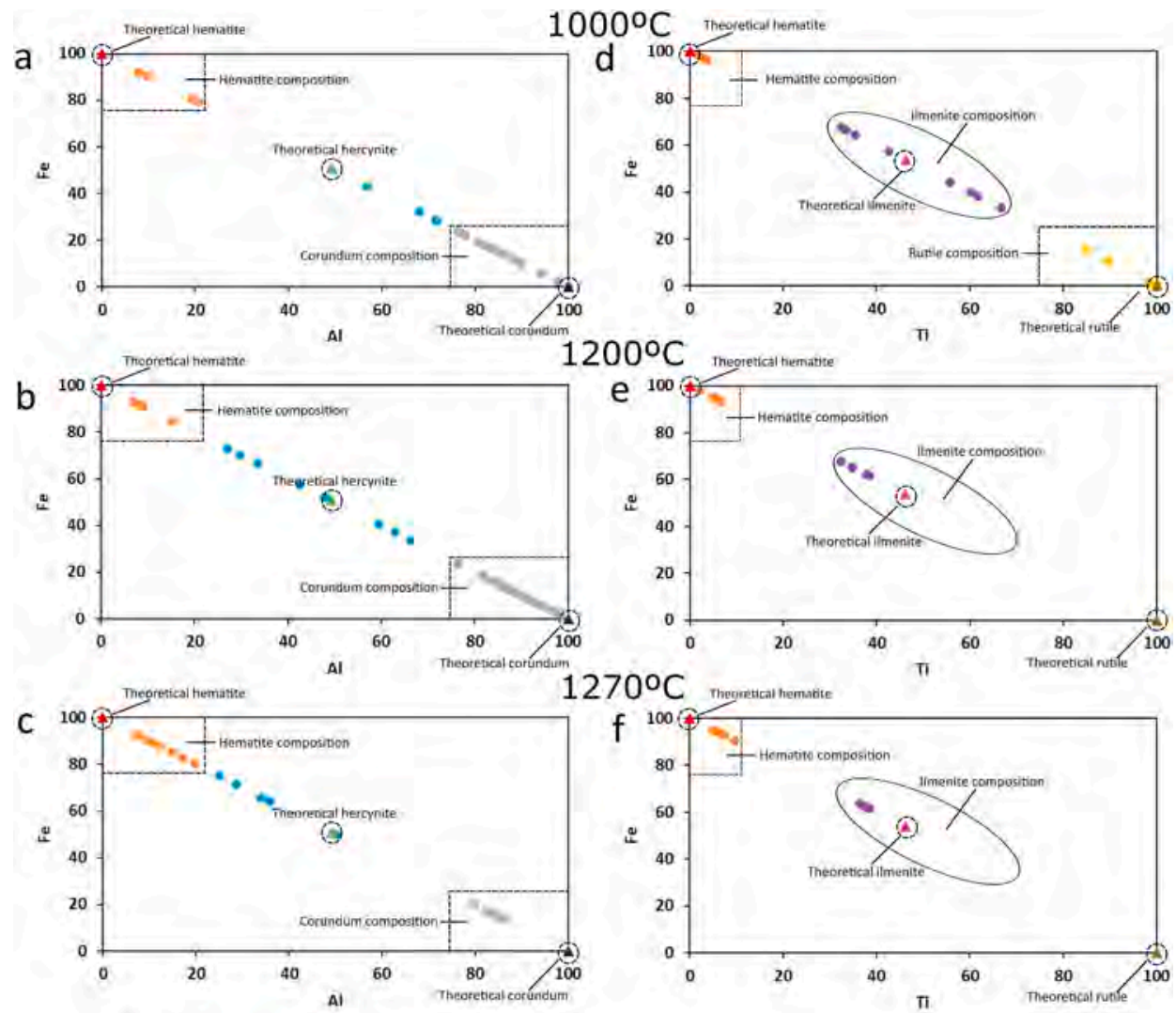

$1270^{\circ} \mathrm{C}$ thenentathematio
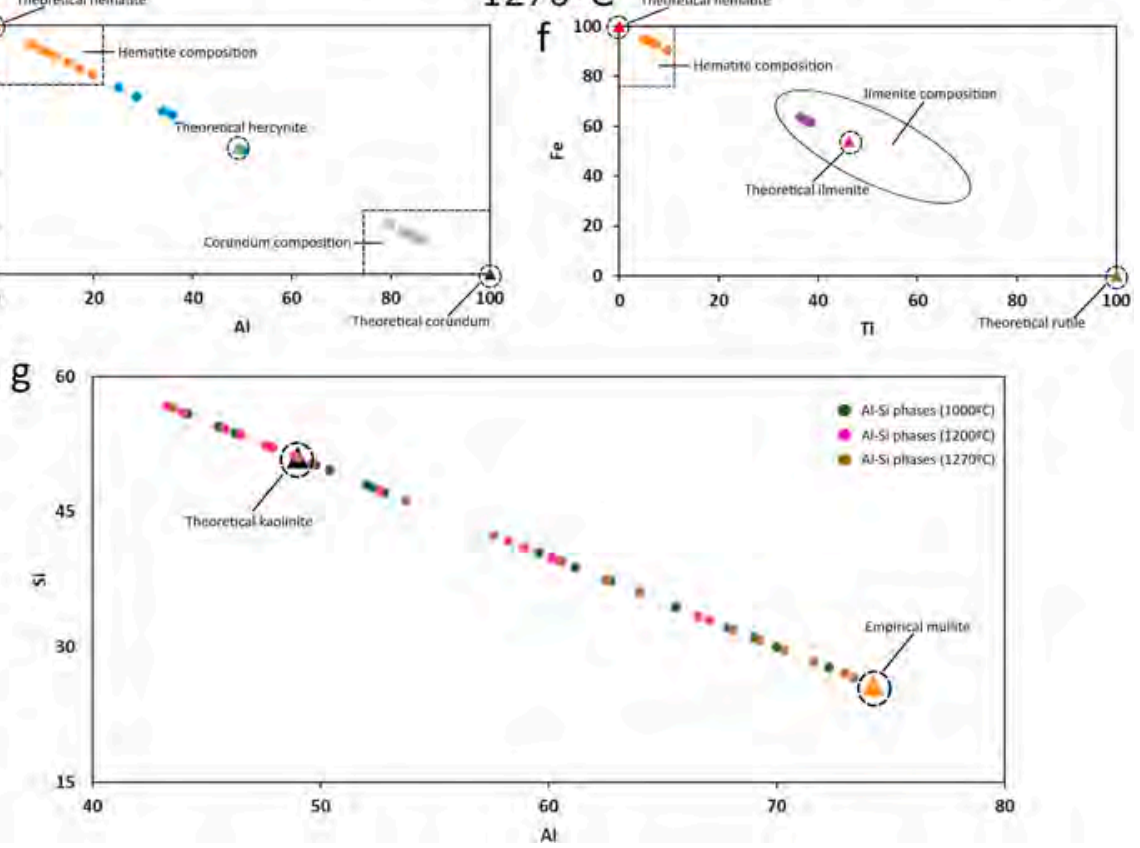

Fig. 8. (a, b, c) Al vs. Fe plots showing the hematite-hercynite-corundum trend in all the samples at 1000,1200 and $1270{ }^{\circ} \mathrm{C}$ respectively. (d, e, f) Ti vs. Fe plots showing ilmenite, rutile and hematite compositions in all the samples at 1000,1200 and $1270{ }^{\circ} \mathrm{C}$. (g) $\mathrm{Al}$ and Si-rich compositions obtained from the mullite crystals in the three samples at the different temperatures.
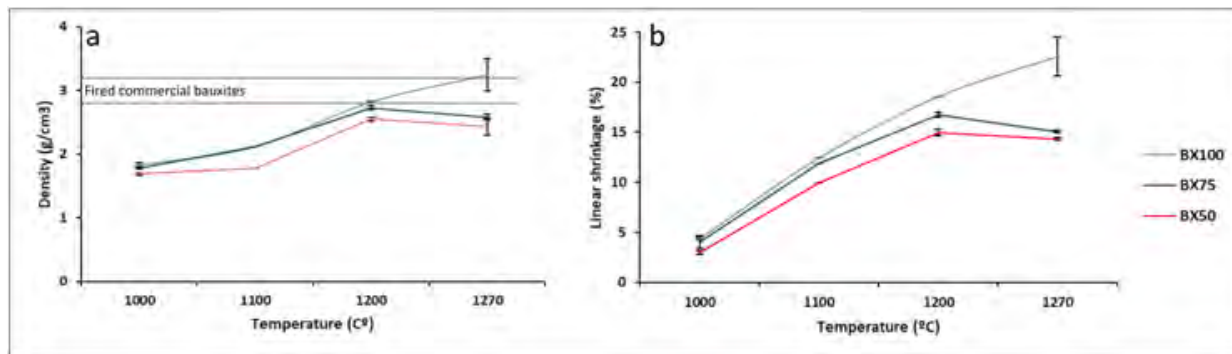

Fig. 9. Density vs temperature (a) and linear shrinkage vs temperature (b) graphs representing the changes in these properties in the fired samples.

reddish brown at 1000 and $1100{ }^{\circ} \mathrm{C}$ and to dull reddish brown from $1200{ }^{\circ} \mathrm{C}$. BX50 undergoes more colour changes with temperature. The raw sample is a dull reddish brown colour, which changes to orange at $1000^{\circ} \mathrm{C}$, then to bright reddish brown at $1100^{\circ} \mathrm{C}$, dull reddish brown at
$1200{ }^{\circ} \mathrm{C}$, and finally to greyish brown at $1270{ }^{\circ} \mathrm{C}$.

The CIE L*a*b* scale (Fig. 10b) shows that there is a trend towards orange colours from the raw samples to those fired at $1000{ }^{\circ} \mathrm{C}$. From $1100{ }^{\circ} \mathrm{C}$, the $\mathrm{a}^{*}$ and $\mathrm{b} *$ values then decrease progressively, which 
a

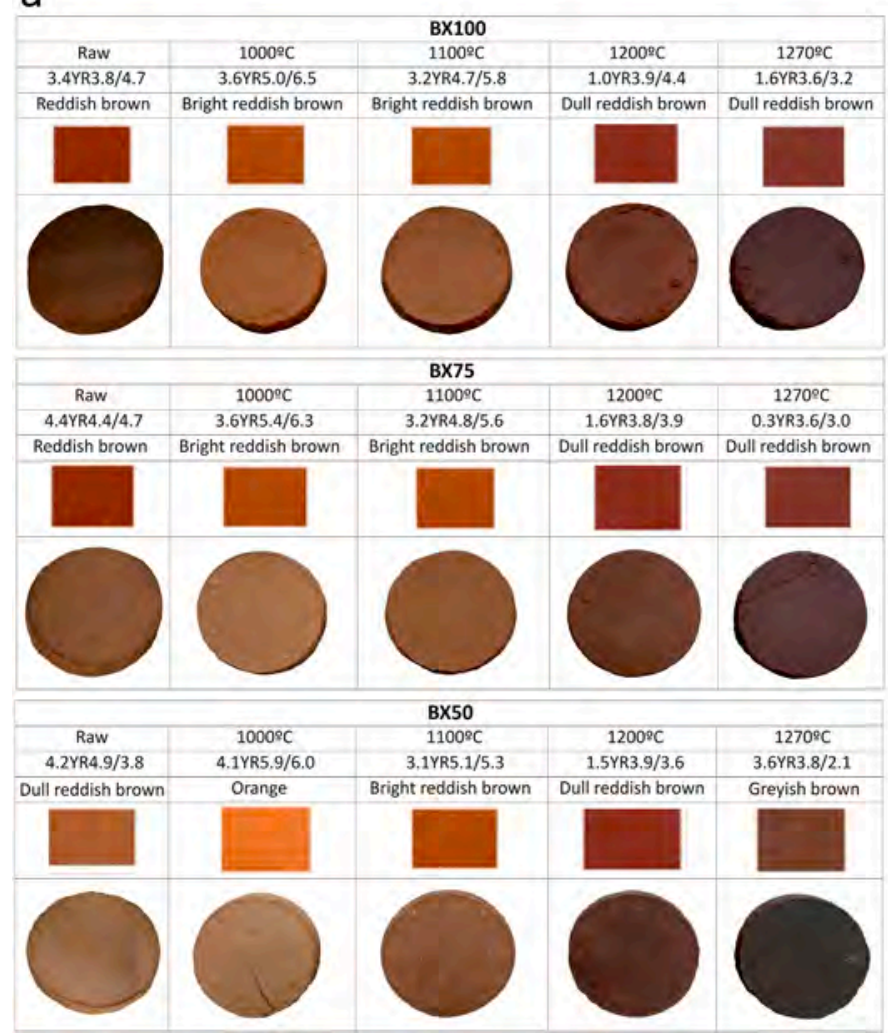

b

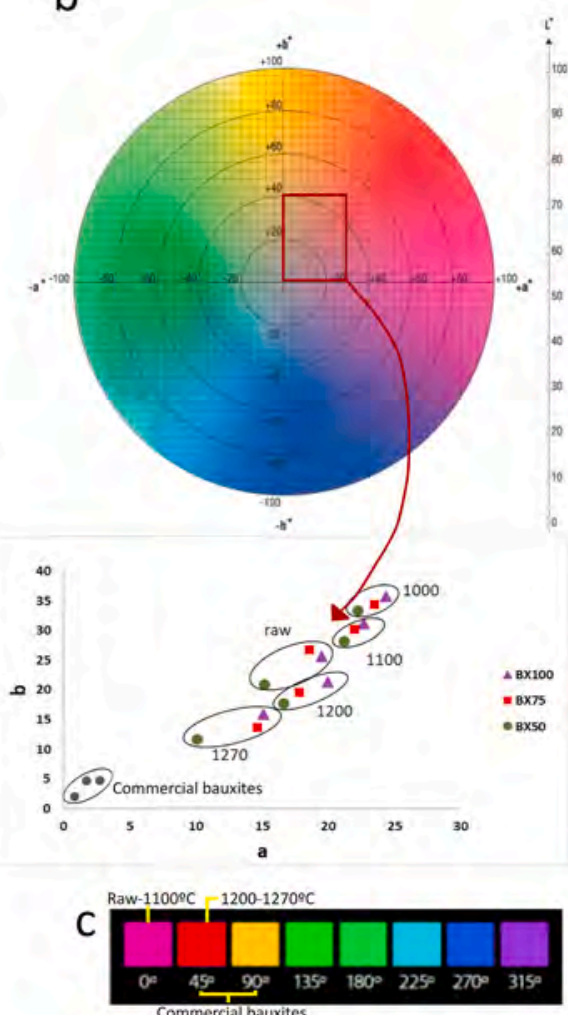

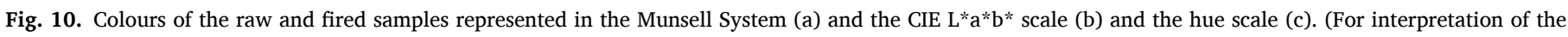
references to colour in this figure legend, the reader is referred to the Web version of this article.)

coincides with the change towards darker colours, also shown by the Munsell System. The hue values calculated for the samples show that all the raw samples and those fired at up to $1100^{\circ} \mathrm{C}$ present values between $34.22^{\circ}$ and $37.03^{\circ}$, which coincide with pink hues, whereas those fired at $1200{ }^{\circ} \mathrm{C}$ and $1270{ }^{\circ} \mathrm{C}$ present hues close to red $\left(40.36^{\circ}\right.$ and $\left.46.94^{\circ}\right)$, according to the hue scale displayed in Fig. 10c.

Comparing these colour values with those of the fired commercial bauxites, the Munsell notation for the fired commercial bauxites (2.1Y5.1/0.7, 1.6Y4.8/0.8 and 5.7Y4.1/0.2) indicates that the latter are of yellowish grey and grey colours, which are darker in colour than the fired cylinders. Likewise, the $\mathrm{a}^{*}$ and $\mathrm{b}^{*}$ coordinates presented by the fired commercial bauxites show lower values than the samples fired at $1270{ }^{\circ} \mathrm{C}$, and their hue values are somewhat higher $\left(63.89-75.86^{\circ}\right)$, indicating hues between red and orange.

\subsubsection{Porosity}

The distribution curves for porosity vary with the increase in firing temperature in all the samples (Fig. 11). At $1000{ }^{\circ} \mathrm{C}$ the intrusion percentage is highest in sample BX50 (4.19\%) and it occurs in pores whose radius reaches greater sizes $(1 \mu \mathrm{m})$ than in samples BX75 and BX100. At

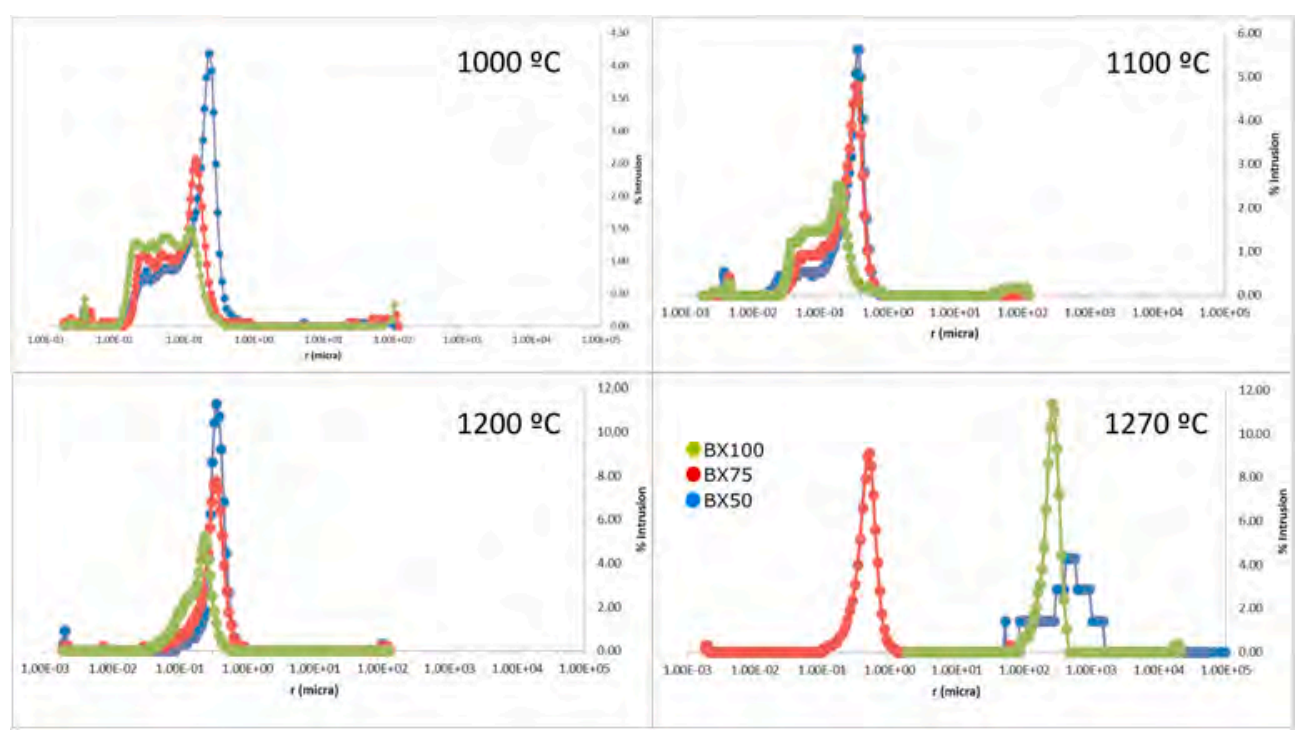

Fig. 11. Distribution curves for porosity obtained from the porosimetric analysis of the fired samples. 
this temperature, sample BX100 presents the lowest intrusion percentage (1.23-1.46\%), with pores with a radius between $2 \times 10^{-2}$ and $3 \times$ $10^{-1} \mu \mathrm{m}$

At 1100 and $1200{ }^{\circ} \mathrm{C}$ the intrusion percentage increases in all the samples, this increase being higher in samples BX50 and BX75, which present a maximum intrusion of $5.62-11.31 \%$ and $4.79-7.78 \%$, respectively. By contrast, sample BX100 has a maximum intrusion of $2.51 \%$, occurring in pores with a radius of $4 \times 10^{-2}-4 \times 10^{-1} \mu \mathrm{m}$, somewhat smaller than those where the maximum intrusion occurs in samples BX75 and BX50.

Finally, at $1270{ }^{\circ} \mathrm{C}$ the maximum intrusion decreases in sample BX50 $(4.29 \%)$ but it occurs in pores with a greater radius than at lower temperatures $\left(3.5 \times 10^{2}\right.$ and $\left.5.6 \times 10^{2} \mu \mathrm{m}\right)$. By contrast, the maximum intrusion increases in samples BX75 (9.13\%) and BX100 (11.38\%). In the case of sample BX75 it occurs in pores with a radius of $1 \times 10^{-1}-1 \mu \mathrm{m}$, whereas in sample BX100 it occurs in pores with a similar radius to those in sample BX50 at this temperature $\left(1 \times 10^{2}-5 \times 10^{2} \mu \mathrm{m}\right)$.

The mean, mode and total porosity of the fired samples are presented in Table 2. The average pore size (mean) decreases in all the samples with the increase in temperature. The mode values also decrease with temperature in samples BX75 and BX100 but increase in sample BX50. The total porosity decreases progressively with temperature in all the samples, although there is a slight increase in sample BX75 at $1270{ }^{\circ} \mathrm{C}$.

The apparent porosity values given for the fired commercial bauxites are between 7 and 14.5\%, which are consistent with the values for all the fired samples at $1200{ }^{\circ} \mathrm{C}$ and even at $1270{ }^{\circ} \mathrm{C}$ in the case of sample BX100.

\subsubsection{Water absorption, thermal conductivity, and point load test}

The water absorption values show that in general the absorption capacity of samples BX100 and BX50 decreases with temperature, whereas that of sample BX75 decreases up to $1100{ }^{\circ} \mathrm{C}$ and then slightly increases (Fig. 12a). This coincides with the decrease in porosity with temperature in all the samples and also with the subsequent slight increase in porosity of sample BX75 at $1270{ }^{\circ} \mathrm{C}$. The fired commercial bauxites have absorption capacity values between 2 and $4.5 \%$, i.e. very close to those of sample BX75 at $1200-1270{ }^{\circ} \mathrm{C}$. In addition, the water absorption values of samples BX100 and BX50 fired at $1100-1200{ }^{\circ} \mathrm{C}$ are also fairly close to the fired commercial bauxite values.

The average values for thermal conductivity $(\mathrm{k})$ obtained for the samples fired at $1200{ }^{\circ} \mathrm{C}$ are represented in Fig. 12b. This shows that samples BX75 and BX100 have a similar k value $(2.46$ and $2.40 \mathrm{~W} / \mathrm{m} . \mathrm{K}$, respectively), which is greater than that of sample BX50 (1.94 W/m.K).

The results for the point load test (Fig. 12c) show that sample BX100 presents the highest resistance when it is fired at the highest temperature $\left(1270{ }^{\circ} \mathrm{C}\right)$. By contrast, sample BX50 presents higher resistance, even higher than that shown by sample BX100, at $1200{ }^{\circ} \mathrm{C}$ than at $1270{ }^{\circ} \mathrm{C}$, whereas there is no significant change in the resistance values for sample BX75 between these temperatures.

Table 2

Mean, mode and total porosity values obtained from the porosimetric analysis of the fired samples.

\begin{tabular}{lllll}
\hline & & Mean $(\mu \mathrm{m})$ & Mode $(\mu \mathrm{m})$ & Total porosity $(\%)$ \\
\hline BX50 & 1000 & $6.67 \mathrm{E}-02$ & $1.39 \mathrm{E}+00$ & 34.55 \\
& 1100 & $4.46 \mathrm{E}-02$ & $1.96 \mathrm{E}+00$ & 25.69 \\
& 1200 & $1.61 \mathrm{E}-02$ & $2.07+00$ & 9.01 \\
BX75 & 1270 & $3.05 \mathrm{E}-03$ & $3.21 \mathrm{E}+00$ & 0.19 \\
& 1000 & $1.34 \mathrm{E}-01$ & $2.28 \mathrm{E}+00$ & 34.67 \\
& 1100 & $7.07 \mathrm{E}-02$ & $2.13 \mathrm{E}+00$ & 23.92 \\
& 1200 & $2.31 \mathrm{E}-02$ & $3.98 \mathrm{E}-01$ & 14.45 \\
BX100 & 1270 & $3.34 \mathrm{E}-02$ & $1.79 \mathrm{E}-02$ & 18.13 \\
& 1000 & $7.09 \mathrm{E}-02$ & $2.63 \mathrm{E}+00$ & 40.41 \\
& 1100 & $4.38 \mathrm{E}-02$ & $8.63 \mathrm{E}-01$ & 29.16 \\
& 1200 & $1.78 \mathrm{E}-02$ & $6.40 \mathrm{E}-02$ & 17.08 \\
& 1270 & $9.70 \mathrm{E}-03$ & $4.01 \mathrm{E}-02$ & 9.73 \\
\hline
\end{tabular}

\section{Discussion}

\subsection{Mineral and textural changes during the firing process}

\subsubsection{Destabilization of the initial phases}

As pointed out in the Result sections, the raw samples initially contained boehmite, illite and/or kaolinite, hematite, rutile and anatase. Sample BX100 also had goethite, and BX75 and BX50 contained quartz.

Most of these initial phases were destabilized and melted during the firing process. Clay minerals were not detected at $1000{ }^{\circ} \mathrm{C}$, indicating that these minerals are the least stable phases. Previous studies [2] have reported the absence of kaolinite above $800{ }^{\circ} \mathrm{C}$ in aluminium-rich ceramic materials, and the presence of illite up to $1000{ }^{\circ} \mathrm{C}$, but with clear signs of dehydroxylation processes from $450{ }^{\circ} \mathrm{C}$. The low stability of kaolinite in ceramic materials has also been reported by other authors $[22,23]$, who describe the presence between 500 and $1000{ }^{\circ} \mathrm{C}$ of amorphous metakaolinite, which would be the precursor of mullite. The kaolinite-type morphologies observed in the fired samples at $1000{ }^{\circ} \mathrm{C}$ (Fig. 5d and f) could correspond, at least in part, to metakaolinite, given the closeness of their composition to the theoretical kaolinite. Nevertheless, taking into account the presence of mullite as deduced from XRD and the lack of FESEM evidence for discrete mullite crystals, they could also correspond to mullite and would thus represent the pseudomorphic transformation from kaolinite to mullite, since there is no evidence of fusion processes affecting the kaolinite-type morphologies at this temperature.

In the case of illite, thermogravimetric analysis also reported dehydroxylation occurring at $500-550{ }^{\circ} \mathrm{C}$ [24].

Like the clay minerals, boehmite was not present at $1000{ }^{\circ} \mathrm{C}$ due to a dehydration process that transforms boehmite $\left(\gamma\right.$-AlOOH) into $\gamma-\mathrm{Al}_{2} \mathrm{O}_{3}$ at $490-510{ }^{\circ} \mathrm{C}$ [25-27]. Furthermore, neither the small amounts of anatase detected in all the raw samples nor the goethite detected in sample BX100 were present at $1000{ }^{\circ} \mathrm{C}$. This can be explained by the fact that goethite dehydrated into hematite at $500-600{ }^{\circ} \mathrm{C}[28,29]$ and that anatase transforms into rutile at 500-550 ${ }^{\circ} \mathrm{C}$ [30]. In addition, the presence of small amounts of amorphous or poor crystalline iron oxides (not detected by XRD in the raw samples) that would destabilize with temperature, along with the dehydration of goethite into hematite in sample BX100, may be the cause of the increase in the hematite content at $1000^{\circ} \mathrm{C}$ in all the samples.

The quartz content also increased at this temperature in samples BX75 and BX50. This may be a consequence of kaolinite and illite destabilization, which gives rise to an amorphous $\mathrm{SiO}_{2}$ phase at 925$1050{ }^{\circ} \mathrm{C}[31]$.

\subsubsection{Crystallization and composition of new phases}

The morphology of synthetic $\gamma$-alumina has been described as irregular or thin flakes [32,33], so the acicular and prismatic crystals observed at $1000{ }^{\circ} \mathrm{C}$ by FESEM probably correspond to corundum.

These corundum crystals are of random orientation and of sizes that increase with temperature, reaching up to $4 \mu \mathrm{m}$ at $1270{ }^{\circ} \mathrm{C}$, and they are immersed in a probably vitreous matrix as well as replacing hematite. Previous studies have described how hematite or magnetite can be replaced by spinel in igneous materials and natural clinkers [34-36]. In this way, the low hercynite proportions detected in the XRD patterns could be replacing hematite, with the hematite content thus decreasing with temperature.

The transformation of pseudo-spinel to $\gamma-\mathrm{Al}_{2} \mathrm{O}_{3}$ has also been described in the literature [37], so the detected hercynite could contribute to the alumina formation.

As commented above, boehmite dehydrates, also giving rise to $\gamma-\mathrm{Al}_{2} \mathrm{O}_{3}$, at $490-510{ }^{\circ} \mathrm{C}$ [25-27]. $\gamma-\mathrm{Al}_{2} \mathrm{O}_{3}$ is one of the seven transition phases of alumina $\left(\chi-\mathrm{Al}_{2} \mathrm{O}_{3}, \kappa-\mathrm{Al}_{2} \mathrm{O}_{3}, \gamma-\mathrm{Al}_{2} \mathrm{O}_{3}, \theta-\mathrm{Al}_{2} \mathrm{O}_{3}, \delta-\mathrm{Al}_{2} \mathrm{O}_{3}, \eta-\mathrm{Al}_{2} \mathrm{O}_{3}\right.$, $\rho-\mathrm{Al}_{2} \mathrm{O}_{3}$ ). The corundum structure is called $\alpha-\mathrm{Al}_{2} \mathrm{O}_{3}$ and is the last and most stable alumina phase, formed by increasing the temperature up to $1200{ }^{\circ} \mathrm{C}[26,38]$. Accordingly, the $\gamma-\mathrm{Al}_{2} \mathrm{O}_{3}$ peaks detected in the XRD 


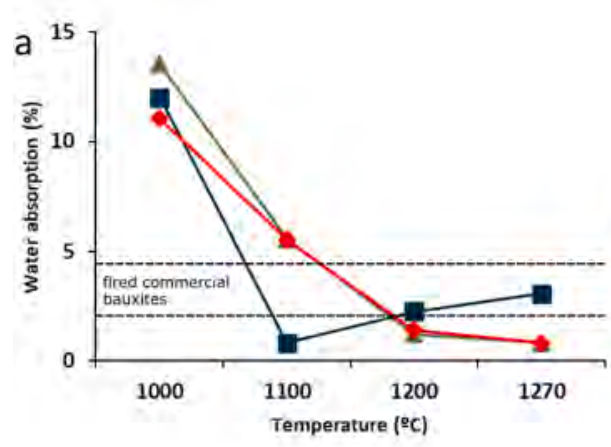

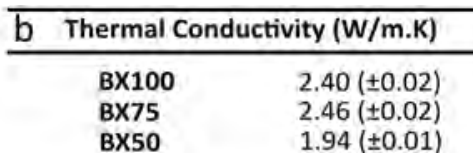

\begin{tabular}{|c|c|c|c|}
\hline \multirow{3}{*}{$\begin{array}{l}-8 \times 100 \\
-8-B \times 75 \\
-8 \times 50\end{array}$} & \multicolumn{3}{|c|}{$\begin{array}{ll}\mathrm{C} & \text { Is(50) (Mpa) }\end{array}$} \\
\hline & \multirow{2}{*}{ BX100 } & 1200 & $0.89( \pm 0.15)$ \\
\hline & & 1270 & $1.32( \pm 0.19)$ \\
\hline & \multirow{2}{*}{ BX75 } & 1200 & $1.12( \pm 0.16)$ \\
\hline & & 1270 & $1.14( \pm 0.16)$ \\
\hline & \multirow{2}{*}{ BX50 } & 1200 & $1.36( \pm 0.15)$ \\
\hline & & 1270 & $1.20( \pm 0.14)$ \\
\hline
\end{tabular}

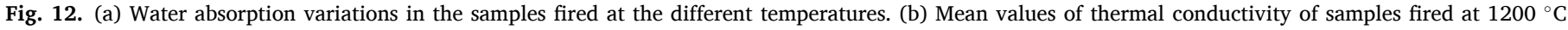
(standard deviation in brackets). (c) Point load index (Is(50)) obtained for samples fired at 1200 and $1270{ }^{\circ} \mathrm{C}$ (standard deviation in brackets).

patterns of the three samples fired at $1000{ }^{\circ} \mathrm{C}$ may be the remains of the transition phases of the alumina from the destabilization of boehmite and hercynite giving rise to corundum formation.

On the other hand, hematite $\left(\alpha-\mathrm{Fe}_{2} \mathrm{O}_{3}\right)$ and corundum $\left(\alpha-\mathrm{Al}_{2} \mathrm{O}_{3}\right)$ are isostructural phases and can form a solid solution at $1000-1300{ }^{\circ} \mathrm{C}$ [39]. This could also explain the compositions intermediate between these two phases in the studied ceramics.

FESEM analysis also showed a compositional trend among hematite, ilmenite and rutile compositions. During firing, part of the Ti from anatase and the Fe from hematite could lead to ilmenite crystallization. Ilmenite and hematite can form a solid solution above $650{ }^{\circ} \mathrm{C}$ [40], which would explain the compositional zonation between hematite and ilmenite found in some grains/crystals. This solid solution results in separated hematite-rich and ilmenite-rich phases with cooling [41]. Rutile, ilmenite and spinel intergrowths have also previously been described in igneous rocks [42] in a similar way to the compositional zonation between rutile and ilmenite observed in the studied samples.

The kaolinite-type morphologies observed at $1000{ }^{\circ} \mathrm{C}$ present their sheets separately due to the dehydroxylation processes, indicating that kaolinite was probably destabilized into metakaolinite. This metakaolinite would be the precursor of mullite through a solid-state process, giving rise to the pseudomorphic formation of mullite at $1000{ }^{\circ} \mathrm{C}$, as commented in section 5.1.1. Later, the fusion process increases, which is evidenced by the presence of a vitreous phase, allowing the formation of discrete mullite crystals, which are clearly distinguished at $1200^{\circ}$ and $1270{ }^{\circ} \mathrm{C}$ in the FESEM images. At these temperatures, mullite is present as acicular and prismatic crystals of random orientation, whose sizes increase with temperature, reaching up to $2 \mu \mathrm{m}$ in length at $1270^{\circ} \mathrm{C}$. The mullite composition is not stoichiometric but follows a trend between kaolinite and empirical mullite compositions, and it shows a higher $\mathrm{Al} /$ Si ratio at $1270^{\circ} \mathrm{C}$. The $\mathrm{Al}$ diffusion was probably higher at $1270^{\circ} \mathrm{C}$ than at $1000{ }^{\circ} \mathrm{C}$ [2], and thus there is an increase in the $\mathrm{Al}$ content of mullite crystals with the increase in temperature. The increase in crystal size and the changes in the composition with temperature are indicative of a decrease in the number of crystalline defects in the mullite structure [2].

\subsubsection{The firing process and the vitreous phase formation}

The vitrification process is responsible for the homogenization in the overall texture of all the samples with increasing temperature. At $1000{ }^{\circ} \mathrm{C}$ the rock fragments from the bauxite and the illite- and kaoliniterich clay are still recognized, but they are no longer so distinguishable at $1200-1270{ }^{\circ} \mathrm{C}$. The bauxite rock fragments seem to be more stable with temperature, since they are better recognizable at these temperatures in sample BX100; this may be due to its higher corundum content, as materials with high alumina content can withstand temperatures greater than $1300{ }^{\circ} \mathrm{C}$ and thermal shocks [43].

The presence of the vitreous phase is deduced in the three samples from the XRD and FESEM results from $1000{ }^{\circ} \mathrm{C}$ upwards. The FESEM analyses showed that this vitreous phase presents compositional variations depending on the sample and the area analysed, but in general it has an $\mathrm{Al}$ - and Si-rich composition and also contains $\mathrm{Fe}$ and minor proportions of $\mathrm{Ti}, \mathrm{Mg}, \mathrm{Ca}$ and $\mathrm{Na}$. The $\mathrm{Al}$ and $\mathrm{Si}$ come from illite, kaolinite, boehmite and quartz, which were the main components of the raw samples and could also contribute $\mathrm{Mg}$, $\mathrm{Ca}$ and $\mathrm{Na}$, whereas the $\mathrm{Fe}$ and Ti come from hematite and from anatase and rutile, respectively.

The fact that the newly generated phases such as corundum or mullite are immersed in the vitreous phase demonstrates that the initial phases destabilized with the increase in temperature, giving rise to this vitreous phase from which the new phases crystallized from $1100{ }^{\circ} \mathrm{C}$ on.

On the other hand, these new phases are non-stoichiometric, which may be due to the dynamics of the firing process resulting in incomplete mineral reactions [2]. According to these authors, the aluminium diffusion is probably lower at $1000{ }^{\circ} \mathrm{C}$ than at $1270{ }^{\circ} \mathrm{C}$, which is supported by the compositional trend of mullite towards a higher $\mathrm{Al} / \mathrm{Si}$ ratio at $1270{ }^{\circ} \mathrm{C}$ and by the high amounts of corundum crystallized in all the samples.

\subsection{Changes in physical properties during the firing process}

\subsubsection{Changes in physical properties and their relation to the mineral transformations}

The increase in density with temperature in all the samples may be associated with the formation of the vitreous phase that gives rise to mullite crystallization, as has been described in kaolinite-rich clay materials [44]. By contrast, the increase in linear shrinkage may be associated with the dehydroxylation of the phyllosilicates and hydroxides during the firing process. On the other hand, the slight decrease in these two properties detected at $1270{ }^{\circ} \mathrm{C}$ in samples BX75 and BX50 could be due to the formation of internal fractures during firing, which may not be observable to the naked eye.

The red colours of the fired clays can be attributed to the presence of $\mathrm{Fe}_{2} \mathrm{O}_{3}$ [11], as well as to its crystal size and distribution. The colour change from brown to reddish colours at $1000{ }^{\circ} \mathrm{C}$ may be related with the increase in hematite content at this temperature. Similarly, the decrease in hematite content at $1200^{\circ}$ and $1270^{\circ}$ would cause the colour change from reddish to grey colours. The CIE L*a*b* scale reflects a decrease in the $a^{*}$ and $b^{*}$ values with the increase in temperature, which is more marked in samples BX75 and BX50. Decreases in $a^{*}$ and b* values with rising temperature have also been described in clayey materials in the literature [45], so the decrease in these values in samples BX75 and BX50 may be associated with their higher clay content and lower hematite content.

The continuous pore filling by mullite and vitreous phase is also the consequence of the decrease in the total porosity of the samples, which decreased progressively with the increase in temperature in the studied samples, especially at $1200{ }^{\circ} \mathrm{C}$, when the vitreous phase and mullite content is higher in all the samples. A decrease in porosity with temperature due to the formation of vitreous phase has also been reported in 
similar materials $[3,46]$.

The increase in the density and linear shrinkage correlates with the decreases in water absorption, which has also been described in clayey materials [11]. The decrease in water absorption is also related with the decrease in total porosity [46] and/or in pore size and connectivity. Higher pore connectivity, along with the possible internal fractures produced during firing as commented above, would explain the slight increase in porosity and water absorption in sample BX75 at $1200-1270{ }^{\circ} \mathrm{C}$. The maximum helium intrusion in this sample at $1270{ }^{\circ} \mathrm{C}$ occurred in pores with a smaller radius than in samples BX100 and BX50, but these pores may have been more connected, leading to a small increase in porosity and water absorption capacity.

The thermal conductivity values obtained for the samples fired at $1200{ }^{\circ} \mathrm{C}$ are higher when the total porosity and density are higher and the pore mode values are lower. Sample BX50 presents the lowest $\mathrm{k}$ value, which coincides with a higher pore mode, but a lower total porosity caused by a higher vitreous phase content. Conversely, samples BX100 and BX75 have higher k values, which correlate with a lower pore mode, but a higher total porosity caused by a lower vitreous phase content.

Finally, the point load test indicated that sample BX50 has higher resistance at $1200^{\circ} \mathrm{C}$ than at $1270{ }^{\circ} \mathrm{C}$, whereas the opposite was the case for sample BX100. This may be related with the mullite and corundum content, since at $1270{ }^{\circ} \mathrm{C}$ sample $\mathrm{BX} 100$ has a higher corundum content, whereas sample BX50 presents a higher mullite content.

\subsubsection{Refractory potential of the studied materials}

The fired commercial bauxites were mainly formed by corundum (67-80\%) and mullite (13-26\%). The most similar composition to this among the studied ceramics is that of sample BX100 fired at $1100{ }^{\circ} \mathrm{C}$ ( $57 \%$ corundum and $21 \%$ mullite), whereas samples BX75 and BX50 are poor in corundum and rich in mullite from $1000{ }^{\circ} \mathrm{C}$ upwards.

By contrast, some of the physical properties of samples BX75 and BX50 are closer to those of the fired commercial bauxites than those of sample BX100. In addition, the firing temperature is also an important factor, as commented above, since it causes changes in all the measured physical properties.

Sample BX100 fired at $1270{ }^{\circ} \mathrm{C}$ presents a density $\left(3.43 \mathrm{~g} / \mathrm{cm}^{3}\right)$ similar to those of the fired commercial bauxites $\left(2.8-3.23 \mathrm{~g} / \mathrm{cm}^{3}\right)$, whereas BX75 and BX50 present a slightly lower density at this temperature $\left(2.55 \mathrm{~g} / \mathrm{cm}^{3}\right.$ and $2.43 \mathrm{~g} / \mathrm{cm}^{3}$, respectively), which, as suggested above, may be caused by the presence of internal fractures. The porosity of samples BX75 and BX50 fired at $1200{ }^{\circ} \mathrm{C}(9.01$ and $14.45 \%$ respectively) and that of sample BX100 (9.73\%) fired at $1270{ }^{\circ} \mathrm{C}$ are those that fit best with the porosity of the fired commercial bauxites (7-14.5\%). This indicates that the mixture of the bauxite with the illite- and kaolinite-rich clay also produces a decrease in porosity at lower temperatures.

The water absorption values of sample BX75 fired at $1200-1270{ }^{\circ} \mathrm{C}$ $(2.25-3.09 \%)$ are similar to those of the fired commercial bauxites, whereas samples BX100 and BX50 fired at $1100-1200{ }^{\circ} \mathrm{C}$ present water absorption values outside those limits, though close to them. Regarding the colour, samples BX50 and BX75 presented lower $\mathrm{a}^{*}$ and $\mathrm{b}^{*}$ values with increasing temperature, and they are closest to the $a^{*}$ and $b^{*}$ values of fired commercial bauxite when fired at $1270{ }^{\circ} \mathrm{C}$. This could indicate that, due to the mixture of the bauxite with the illite- and kaolinite-rich clay, the hematite content is lower, and thus samples are darker.

The thermal conductivity of the samples is related with their porosity and vitreous phase content. To be a suitable refractory material, thermal conductivity should be as low as possible. According to our results, a sample mixed $50 \%$ with illite- and kaolinite-rich clay presents better values of thermal conductivity $(1.94 \mathrm{~W} / \mathrm{m} . \mathrm{K})$ than the pure bauxite $(2.40 \mathrm{~W} / \mathrm{m} . \mathrm{K})$ at the same firing temperature. Finally, the higher resistance observed in samples BX50 and BX75 at $1200{ }^{\circ} \mathrm{C}$ in the point load test may be related with a higher mullite and vitreous phase content at this temperature in these samples. The presence of illite and kaolinite gives rise to an increase in resistance due to the higher $\mathrm{K}$ content (as was also reported by the XRF results), which reduces the melting point and results in earlier vitrification and/or more effective formation of vitreous phase. By contrast, the higher resistance of sample BX100 at $1270{ }^{\circ} \mathrm{C}$ may be associated with its corundum content, which is higher at this temperature.

Therefore, pure bauxite fired at $1270^{\circ} \mathrm{C}$ shows characteristics closely resembling those of the fired commercial bauxites regarding mineralogical composition, porosity and density, and it shows high resistance. However, mixtures of bauxite with illite- and kaolinite-rich clays fired at lower temperatures show features not so far from the ranges exhibited by the fired commercial bauxites, but they are richer in mullite and vitreous phase, which lead to higher resistance and (in the case of sample BX50) lower thermal conductivity of the fired products.

\section{Conclusions}

The study of mixtures of bauxite with illite- and kaolinite-rich clays fired between 1000 and $1270{ }^{\circ} \mathrm{C}$ shows mineralogical and textural changes during firing that clearly affect the physical properties of the materials.

At $1000{ }^{\circ} \mathrm{C}$, the formation of mullite seems to occur as a pseudomorphic, solid-state process after amorphous metakaolinite has originated through kaolinite dehydroxylation. At higher temperatures, the ongoing destabilization of the initial phases gives rise to a $\mathrm{Si}$ - and $\mathrm{Al}$-rich vitreous phase from which cristobalite, ilmenite, hercynite, mullite and corundum crystallize. The vitrification process causes the textural homogenization of the samples with increasing temperature and the short duration of the firing process allows the coexistence of some of the initial phases with those generated during the firing.

Mullite and corundum are the most abundant phases at a high temperature, the mullite content being higher in those samples mixed with the illite- and kaolinite-rich clay. Both phases are immersed in the vitreous phase and their crystal thickness increases with temperature up to $2-4 \mu \mathrm{m}$. The analysed mullite presents a heterogeneous composition, but its $\mathrm{Al}$ content increases with temperature.

The formation of vitreous phase and mullite and the process of dehydroxylation, gives rise to an increase in the density and linear shrinkage that correlates with a decrease in total porosity, water absorption and thermal conductivity. The changes in the colour are related to the hematite content, whereas the resistance of the samples is associated with their vitreous phase and corundum content.

Both the firing temperature and the clay content influence the refractory potential of the mixtures, since samples mixed with illite- and kaolinite-rich clay present similar properties at lower temperatures to those of the fired commercial bauxites. This study shows that when mixing bauxite with Al-K-bearing clays, it is not necessary to reach such high firing temperatures to achieve refractory properties like those of fired commercial materials.

\section{Declaration of competing interest}

The authors declare that they have no known competing financial interests or personal relationships that could have appeared to influence the work reported in this paper.

\section{Acknowledgments}

This work was supported by the European Regional Development Fund and the Government of Aragon [Aragosaurus Group: Geological Resources and Palaeoenvironments, grant number E18_20R] and the Spanish Ministry of Science, Innovation and Universities [grant number RTI2018-093419-B-100]. The authors would like to acknowledge the use of the Servicio General de Apoyo a la Investigación-SAI, University of Zaragoza. They would also like to thank Cristina Gallego for her advice during the FESEM sessions and Miguel Castro for his help and 
advice with the thermal conductivity measurements. Elisa Laita is also grateful for a Government of Aragón grant for the development of her Ph.D. The authors would also like to thank the reviewers, whose comments and suggestions helped to improve the manuscript.

\section{References}

[1] I.A. Altun, Effect of temperature on the mechanical properties of self-flowing low cement refractory concrete, Cement Concr. Res. 31 (2001) 1233-1237, https://doi org/10.1016/S0008-8846(01)00533-6.

[2] E. Laita, B. Bauluz, Mineral and textural transformations in aluminium-rich clays during ceramic firing, Appl. Clay Sci. 152 (2018) 284-294, https://doi.org/ 10.1016/j.clay.2017.11.025.

[3] O.V. Gavshina, V.A. Doroganov, E.A. Doroganov, V.I. Onishehuk, Y.N. Trepalina, High-alumina mixes based on molded bauxite suspensions, Refract. Ind. Ceram. 60 (4) (2019) 350-354, https://doi.org/10.1007/s11148-019-00365-3.

[4] M.M. Jordán, S. Meseguer, F. Pardo, M.A. Montero, High-temperature mineral formation after firing clay materials associated with mined coal in teruel (Spain), Appl. Sci. 10 (2020) 3114, https://doi.org/10.3390/app10093114.

[5] M. Maggetti, Phase analysis and its significance for technology and origin, in: J. S. Olin (Ed.), Archaeological Ceramics Smithsonian, Institution Press, Boston, 1982, pp. 121-133.

[6] M. Ghassemi Kakroudi, E. Yeugo-Fogaing, C. Gault, M. Huger, T. Chotard, Effect of thermal treatment on damage chemical behaviour of refractory castables: comparison between bauxite and andalusite aggregates, J. Eur. Ceram. Soc. 28 (2008) 2471-2478, https://doi.org/10.1016/j.jeurceramsoc.2008.03.048.

[7] B. Bauluz, M.J. Mayayo, A. Yuste, C. Fernández-Nieto, J.M. González López, TEM study of mineral transformations in fired carbonated clays: relevance to brick making, Clay Miner. 39 (2004) 333-344, https://doi.org/10.1180/ 0009855043930138

[8] M.M. Jordán, A. Boix, T. Sanfeliu, C. de la Fuente, Firing transformations of cretaceous clays used in the manufacturing of ceramic tiles, Appl. Clay Sci. 14 (1999) 225-234, https://doi.org/10.1016/S0169-1317(98)00052-0.

[9] F. Pardo, S. Meseguer, M.M. Jordán, T. Sanfeliu, I. González, Firing transformations of Chilean clays for the manufacture of ceramic tile bodies, Appl. Clay Sci. 51 (2011) 147-150, https://doi.org/10.1016/j.clay.2010.11.022.

[10] S. Boussen, D. Sghaier, F. Chaabani, B. Jamoussi, A. Bennour, Characteristics and industrial application of the Lower Cretaceous claydeposits (Bouhedma Formation), Southeast Tunisia: potential use for the manufacturing of ceramic tiles and bricks, Appl. Clay Sci. 123 (2016) 210-221, https://doi.org/10.1016/j. clay.2016.01.027.

[11] B. Semiz, S.B. Celik, Mineralogical and geochemical characteristics of Belevi clay deposits at Denizli, SW Turkey: industrial raw material potential, Arab. J. Geosci. 13 (2020) 313, https://doi.org/10.1007/s12517-020-05292-z.

[12] F. Yang, C. Li, Y. Li, C.-A. Wang, Effects of sintering temperature on properties of porous mullite/corundum ceramics, Mater. Lett. 73 (2012) 36-39. https://10.10 16/j.matlet.2011.12.087

[13] J.M. Molina, P.A. Ruiz-Ortiz, J.A. Vera, A. Calonge, Bauxitas kársticas de la sierra de Boada (Sierras Marginales surpirenaicas, Alós de Balaguer, Lleida), Geogaceta 16 (1994) 148-150.

[14] M.J. Aguilar, J. Ramírez del Pozo, O. Riba, Algunas precisiones sobre la sedimentación y paleontología del Cretácico inferior en la zona de UtrillasVillarroya de los Pinares, Estud. Geol. 27 (1971) 497-512.

[15] A. Cervera, G. Pardo, J. Villena, Algunas precisiones litoestratigráficas sobre la Formación 'Lignitos de Escucha', Tecniterrae 3 (1976) 25-33.

[16] L.A. Díaz Rodríguez, R. Torrecillas, Arcillas cerámicas: una revisión de sus distintos tipos, significados y aplicaciones, Bol. Soc. Esp. Ceram. V. 41 (5) (2002) 459-470.

[17] B. Bauluz, M.J. Mayayo, A. Yuste, J.M. González López, Genesis of kaolinite from Albian sedimentary deposits of the Iberian Range (NE Spain): analysis by XRD, SEM and TEM, Clay Miner. 43 (2008) 459-475, https://doi.org/10.1180/ claymin.2008.043.3.10.

[18] J.D. Martin, A software package for powder x-ray diffraction analysis, Qualitative, Quantitative and Microtexture 121 (2017).

[19] L.G. Schultz, Quantitative interpretation of mineralogical composition from X-ray and chemical data for the Pierre shale, USGS Professional Paper 391-C (1964) $1-131$.

[20] P.E. Biscaye, Mineralogy and sedimentation of recent deep-sea clay in the Atlantic Ocean and adjacent seas and oceans, Geol. Soc. Am. Bull. 76 (1965) 803-832.

[21] D.K. Smith, G.G. Johnson Jr., Digitized database quantification, DDBQ, analysis of complex mixtures using fully digitized patterns, Adv. X Ray Anal. 42 (2000) 276-286.

[22] C.Y. Chen, G.S. Lan, W.H. Tuan, Microstructural evolution of mullite during the sintering of kaolin powder compacts, Ceram. Int. 26 (7) (2000) 715-720, https:// doi.org/10.1016/S0272-8842(00)00009-2.
[23] Y. Meng, G. Gong, D. Wei, Y. Xie, In situ high temperature X-ray diffraction study on high strength aluminous porcelain insulator with the $\mathrm{Al}_{2} \mathrm{O}_{3}-\mathrm{SiO}_{2}-\mathrm{K}_{2} \mathrm{O}-\mathrm{Na}_{2} \mathrm{O}$ system, Appl. Clay Sci. 132-133 (2016) 760-767, https://doi.org/10.1016/j. clay.2016.07.014.

[24] V. Drits, D. McCarty, The nature of structure-bonded $\mathrm{H} 2 \mathrm{O}$ in illite and leucophyllite from dehydration and dehydroxylation experiments, Clay Clay Miner. 55 (1) (2007) 45-48, https://doi.org/10.1346/CCMN.2007.0550104.

[25] D. Panias, A. Krestou, Effect of synthesis parameters on precipitation of nanocrystalline boehmite from aluminate solutions, Powder Technol. 175 (2007) 163-173, https://doi.org/10.1016/j.powtec.2007.01.028.

[26] A.S. Jbara, Z. Othaman, A.A. Ati, M.A. Saeed, Characterization of $\gamma$-Al2O3 nanopowders synthesized by Co-precipitation method, Mater. Chem. Phys. 188 (2017) 24-29, https://doi.org/10.1016/j.matchemphys.2016.12.015.

[27] Y. Dong, M. Zhang, C. Xie, Effect of reaction conditions on agglomeration of aluminium hydroxide in the recovery of waste aluminium-catalyst, Separ. Purif. Technol. 248 (2020) 116978, https://doi.org/10.1016/j.seppur.2020.116978.

[28] K. Jang, V.R.M. Nunna, S. Hapugoda, A. Nguyen, W.J. Bruckard, Chemical and mineral transformations of a low grade goethite ore by dehydroxilation, reduction roasting and magnetic separation, Miner. Eng. 60 (2014) 14-22, https://doi.org/ 10.1016/j.mineng.2014.01.021.

[29] Y. Sun, X. Zhu, Y. Han, Y. Li, P. Gao, Iron recovery from refractory limonite ore using suspension magnetization roasting: a pilot-scale study, J. Clean. Prod. 261 (2020) 121221, https://doi.org/10.1016/j.jclepro.2020.121221.

[30] J.M. Low, B. Curtain, M. Philipps, Z.Q. Liu, M. Ionescu, High temperature diffraction study of in-situ crystallization of nanostructured TiO2 photocatalysts, J. Australas. Ceram. Soc. 48 (2) (2012) 198-204.

[31] T. Ondro, O. Al-Shantir, Š. Csáki, F. Lukác, A. Trník, Kinetic analysis of sintercrystallization of mullite and cristobalite from kaolinite, Thermochim. Acta 678 (2019) 178312, https://doi.org/10.1016/j.tca.2019.178312.

[32] L. Samain, A. Jaworski, M. Edén, D.M. Ladd, D.K. Seo, F.J. Garcia-Garcia, U. Häussermann, Structural analysis of highly porous $\gamma-\mathrm{Al}_{2} \mathrm{O}_{3}$, J. Solid State Chem. 217 (2014) 1-8, https://doi.org/10.1016/j.jssc.2014.05.004.

[33] N. Salahudeen, A. Ahmed, A.H. Al-Muhtaseb, M. Dauda, S.M. Waziri, B.Y. Jibril, Synthesis of gamma alumina from Kankara kaolin using a novel technique, Appl. Clay Sci. 105-106 (2015) 170-177, https://doi.org/10.1016/j.clay.2014.11.041.

[34] A.H. Treiman, Amphibole and hecynite spinel in Shergotty and Zagami: magmatic water, depth of crystallization, and metasomatism, Meteoritics 20 (1984) 229-243, https://doi.org/10.1111/j.1945-5100.1985.tb00862.x.

[35] M. Sandiford, F.B. Neall, R. Powell, Metamorphic evolution of aluminous granulites from Labwor Hills, Uganda, Contrib. Mineral. Petrol. 95 (1987) 217-225, https://doi.org/10.1007/BF00381271.

[36] E. Laita, B. Bauluz, A. Yuste, High-temperature mineral phases generated in natural clinkers by spontaneous combustion of coal, Minerals 9 (4) (2019) 213, https:/ doi.org/10.3390/min9040213.

[37] F.M. Segal, M.F. Correa, R. Bacani, B. Castanheira, M.J. Politi, S. Brochsztain, E. R. Triboni, A novel synthesis route of mesoporous $\gamma$-alumina from polyoxohydroxide aluminum, Mater. Res. 21 (1) (2018), e20170674, https://doi. org/10.1590/1980-5373-MR-2017-0674.

[38] S. Cava, S.M. Tebcherani, S.A. Pianaro, C.A. Paskocimas, E. Longo, J.A. Varela, Structural and spectroscopic analysis of $\gamma-\mathrm{Al}_{2} \mathrm{O}_{3}$ to $\alpha-\mathrm{Al}_{2} \mathrm{O}_{3}-\mathrm{CoAl}_{2} \mathrm{O}_{3}$ phase transition, Mater. Chem. Phys. 97 (2006) 102-108, https://doi.org/10.1016/j. matchemphys.2005.07.057.

[39] A. Feenstra, S. Sämann, B. Wunder, An experimental study of Fe-Al solubility in the system corundum-hematite up to $40 \mathrm{kbar}$ and $1300^{\circ} \mathrm{C}$, J. Petrol. 46 (9) (2005), https://doi.org/10.1093/petrology/egi038, 1881-1832.

[40] D.H. Lindsley, Experimental studies of oxide minerals, Rev. Mineral. Geochem. 25 (1991) 69-106.

[41] W. Tan, C. Yan Wang, H. He, C. Xing, X. Liang, H. Dong, Magnetite-rutile symplectite derived from ilmenite-hematite solid solution in the Xinjie Fe-Ti oxidebearing, mafic-ultramafic layered intrusion (SW China), Am. Mineral. 100 (2015) 2348-2351, https://doi.org/10.2138/am-2015-5435.

[42] G. Markl, Mullite-corundum-spinel-cordierite-plagioclase xenoliths in the Skaergaard Marginal Border Group: multi-stage interaction between metasediments and basaltic magma, Contrib. Mineral. Petrol. 149 (2005) 196-215, https://doi.org/10.1007/s00410-004-0644-5.

[43] E. Medvedovski, Wear-resistant engineering ceramics, Wear 249 (2001) 821-828, https://doi.org/10.1016/S0043-1648(01)00820-1.

[44] A. Andrews, J. Adam, S.K.Y. Gawu, Development of fireclay aluminosilicate refractory from lithomargic clay deposits, Ceram. Int. 39 (1) (2012) 779-783, https://doi.org/10.1016/j.ceramint.2012.06.091.

[45] E. Murad, U. Wagner, Clays and clay minerals: the firing process, Hyperfine Interact. 117 (1988) 337-356.

[46] M. Loutou, R. Hakkou, R. Argane, M. Mansori, L. Grase, R. Svinka, G. Mezinskis, Clayey quarry sludges: thermal transformation, microstructure and technological properties, Waste. Biomass. Valor. 9 (2018) 1805-1815, https://doi.org/10.1007/ s12649-017-9972-3. 